NBER WORKING PAPER SERIES

THE ECONOMY OF ISRAEL

Stanley Fischer

Working Paper No. 1190

NATIONAL BUREAU OF ECONOMIC RESEARCH

1050 Massachusetts Avenue

Cambridge, MA 02138

August 1983

The research reported here is part of the NBER's research program in Economic Fluctuations. Any opinions expressed are those of the author and not those of the National Bureau of Economic Research. 
NBER Working Paper $\|_{1} 1190$

August 1983

The Economy of Israel

$\underline{\text { ABSTRACT }}$

The paper opens with a description of the salient features of the Israeli economy. These consist of a large government sector (the government budget has absorbed more than $80 \%$ of (NNP in some recent years); high levels of defense spending; a large government budget deficit; a large current account deficit (about 20\% of GNP); triple digit inflation; and extensive indexation of both wages and long term financial commitments. A descriptive model of the economy is then presented, which includes the particular asset menu of the Israeli economy, and its properties examined. Finally, the model is used in analyzing aspects of the Israeli inflationary experience. The currency liberalization of 1977, which increased the access of Israelis to foreign assets, shares responsibility for the high rate of inflation. The possibilities of ending the inflation are discussed.

Stanley Fischer Professor of Economics Department of Economics MIT E52-280A Cambridge, MA 02139

$617253-6666$ 
THE ECONOHY OF ISRAEL

Stanley Fischer*

From 1953 to 1973 real GDP in Israel grew at an annual rate of nearly 10\%; over the next nine years the growth rate was only $3 \%$, as Table 1 shows. 1 From 1953 to 1973 , the average inflation rate (CPI) was $7.1 \%$; from 1973 to 1979 the inflation rate averaged more than $40_{10}^{\circ}$; and in the last three years the annual inflation rate has been in the triple digit range.

The aims of this paper are to describe the structure and performance of the Israeli economy, and to account for the worsening of its inflation performance over the last decade. We begin with a description of the current state and stmicture of the economy.

\footnotetext{
*Paper originally prepared for the Carnegie-Rochester Series on Public Policy April, 1983. I am incebted to Jacob Frenkel for meny $r$ lpful discussions which, but for circumstances beyond our control, would have led to this being a joint paper; I an grateful too for his subsequent comments. Zvi Auberbach and Zalman Shiffer of the Bank of Israel patiently helped me in the data maze. Helpful comments were received from Haim Barkai, Rudiger Dornbusch, Mordecai Fraenkel, Edi Karni, and Michael Parkin. Research assistance by David Wilcox and financial support from the National Science Foundation are acknowledged with thanks.
} 
Table 1: Israeli Economic Performance, 1953-1932 (\% p.a.)

\begin{tabular}{lccc}
\hline Period & $1953-1973$ & $1973-1979$ & $1979-1982$ \\
\hline $\begin{array}{l}\text { Growth rate of } \\
\quad 9.9\end{array}$ & 3.4 & 2.3 \\
$\quad$ real GDP & & & \\
Growth rate of & 6.2 & 1.0 & 0.3 \\
$\quad$ per capita GDP & & & \\
Inflation rate & 7.1 & 44.9 & 122.7 \\
$\quad(\mathrm{CPI})$ & & & \\
\hline
\end{tabular}

Source: International Financial Statistics and Bank of Israel Report, 1982.

Table 2: The Allocation of Resources in Israel, 1978-82

(Shares in GNP, \%)

\begin{tabular}{cccccc}
\hline $\begin{array}{l}\text { Private } \\
\text { consumption }\end{array}$ & Gestment & $\begin{array}{c}\text { Government Exports } \\
\text { consumption }\end{array}$ & Imports & Net \\
63.9 & 24.8 & 37.8 & 49.3 & Civilian Defense exports \\
& & & 62.0 & 9.1 & -22.8 \\
\hline
\end{tabular}




\section{The Inflationary Economy.}

GNP per capita in Israel at the end of 1981 was about $\$ 5500,45 \%$ of the United States level, roughly at the levels of Greece, Singapore, and Ireland. ${ }^{2}$ per capita consumption is also about $45 \%$ of the Uaited States level. GNP is around $\$ 22$ billion.

The Structure of Demand: Table 2 provides a first perspective on some special features of the Israeli economy. The consunption and investment shares in GNP are not out of the ordinary. But government consumption is extremely high; the average for the ORCD countries is $17 \%$, with the share even in the case of Sweden being less than $30 \%$. The openness of the economy is shown by the large shares of both exports and imports in GNP, and the balance of trade problem by the magnitude of the import surplus. ${ }^{3}$

The dominant role of government and the magnitude of the government budget deficit are clearly revealed by Table 3 , which is based on InF data. Over the past five years government has on average disposed of more than $70 \%$ of GNP and received more than half of GNP in revenues. The budget deficit has averaged more than $20 \%$ of GNP. Fiscal year $1982 / 3$ shows the effects of the war in Lebanon, with government expenditures reaching an extraordinary 90\% of GNP, and tax revenues exceeding half of GNP as a result of revenue measures imposed in mid1982. It can be seen that defense spending accounts for most of government consumption. The share of resources being used for defense is understated in the national accounts, in particular because conscripts are paid a below market wage. One estimate is that total resources devoted to defense may be $50 \%$ more than the amount estimated in the accounts. 4 
Inflation, the Assets Markets, and Indexation: Figure 1 and Table 4 show CPI inflation rates fourth quarter over fourth quarter. Note in particular that after 1954 the Israeli econony enjoyed a long period of single digit inflation. Even after the 1967 war, the inflation rate remained in single digits until 1973. After the Yom Kippur War there were two years of inflation near $40 \%$, and then a two year decline in the inflation rate in 1976 and 1977. Foreign currency holdings were liberalized at the end of 1977. The inflation rate then increased, but it was only in 1979 that it went above 100\%. Since then the inflation rate has remained in a range above $100 \%$.

Indexation of asset returns and wages has been extensive in Israel for over three decales, despite the fact that the inflation rate was reasonably low and stable for most of the fifties and sixties. ${ }^{5}$ Israeli residents may hold assets with returns indexed to either the price level or the exchange rate. They have also been entitled since the 1977 liberalization to hold foreign bank accounts and foreign currency, up to specified limits.

Table 5 shows the financial asset holdings of the public, excluding ownership of foreign currency and assets held abroad, for which there are no data. Shekel denominated (nominal) assets account for less than $4 \%$ of financial assets. ${ }^{6}$ The bulk of the public's financial assets are indexed to the price level, although only a small part of the indexed assets are marketable. Most index bonds are held indirectly through private pension funds, which are obliged to hold the bonds. ${ }^{7}$ Note the large increase in the share of equity in financial assets during 1982, reflecting a stock market boom.

The significant point about Table 5 is that there are government 
Table 3: The Role of Government

(Shares in GNP,

\begin{tabular}{lcccccc}
\hline & $\begin{array}{c}\text { Government } \\
\text { revenue }\end{array}$ & $\begin{array}{c}\text { Government } \\
\text { expenditure }\end{array}$ & Deficit Defense spending \\
& Total & Taxes & Total & Current & & \\
\hline $1978 / 9-1982 / 3$ & 52.9 & 41.0 & 73.4 & 64.7 & 20.6 & 25.5 \\
$1982 / 3$ & 63.6 & 52.0 & 90.0 & 78.9 & 26.4 & 30.6 \\
\hline
\end{tabular}

Source: IMF. Data are for fiscal years, which start April 1.

Table 4: Inflation Rates, CPI

(\% per annum, fourth quarter over fourth quarter)

\begin{tabular}{lrrrrrrr}
$1967-1973$ & $1973-75$ & $1975-77$ & 1973 & 1979 & 1980 & 1981 & 1982 \\
\hline \multirow{2}{*}{10.6} & 40.0 & 38.0 & 49.2 & 103.4 & 136.1 & 104.6 & 130.4 \\
\hline
\end{tabular}


Table 5: Financial Asset Holdings of the Public, 1981 and 1982

(End of year) $)^{2}$

Category

1. Nominal

Of which: is 1

2. Foreign currency linked

Of which: bank deposits (PATAM)

3. Price index linked

Of which: marketable bonds savings schemes \& time deposits pension funds $\& \quad 31.8$ life insurance

4. Equity shares

of which: bank sharest Total

2.3

12.2

13.0

\begin{tabular}{|c|c|c|}
\hline 1981 & & 1982 \\
\hline $\begin{array}{c}\% \text { of financial } \\
\text { assets }\end{array}$ & $\begin{array}{l}\% \text { of } \\
\text { GNP }\end{array}$ & $\begin{array}{c}\% \text { of financial } \\
\text { assets }\end{array}$ \\
\hline
\end{tabular}

3.6

6.2

3.6

4.1

1.6

20.2

35.1

14.8

21.2

8.9

56.4

97.9

48.3

$\begin{array}{lll}6.3 & 10.9 & 5.0\end{array}$

18.4

31.9

15.7

55.1

27.5

19.8

34.3

33.3

22.6

14.3

100.0

100.0

Notes: l Rest of world onitted, for lack of data, as noted in source.

2 Source: For 1981, based on Table 8-5A, Bank of Israel Report, 1981, (Hebrew edition), p.254; for 1982, based on Table 8-5A in the 1982 Report (Hebrew edition), p.280.

${ }^{3}$ GNP is fourth quarter GNP, IFS data, transformed to annual rate.

${ }^{4}$ Bank shares are noted separately because their stable real rate of return makes them more like index bonds than equity. 


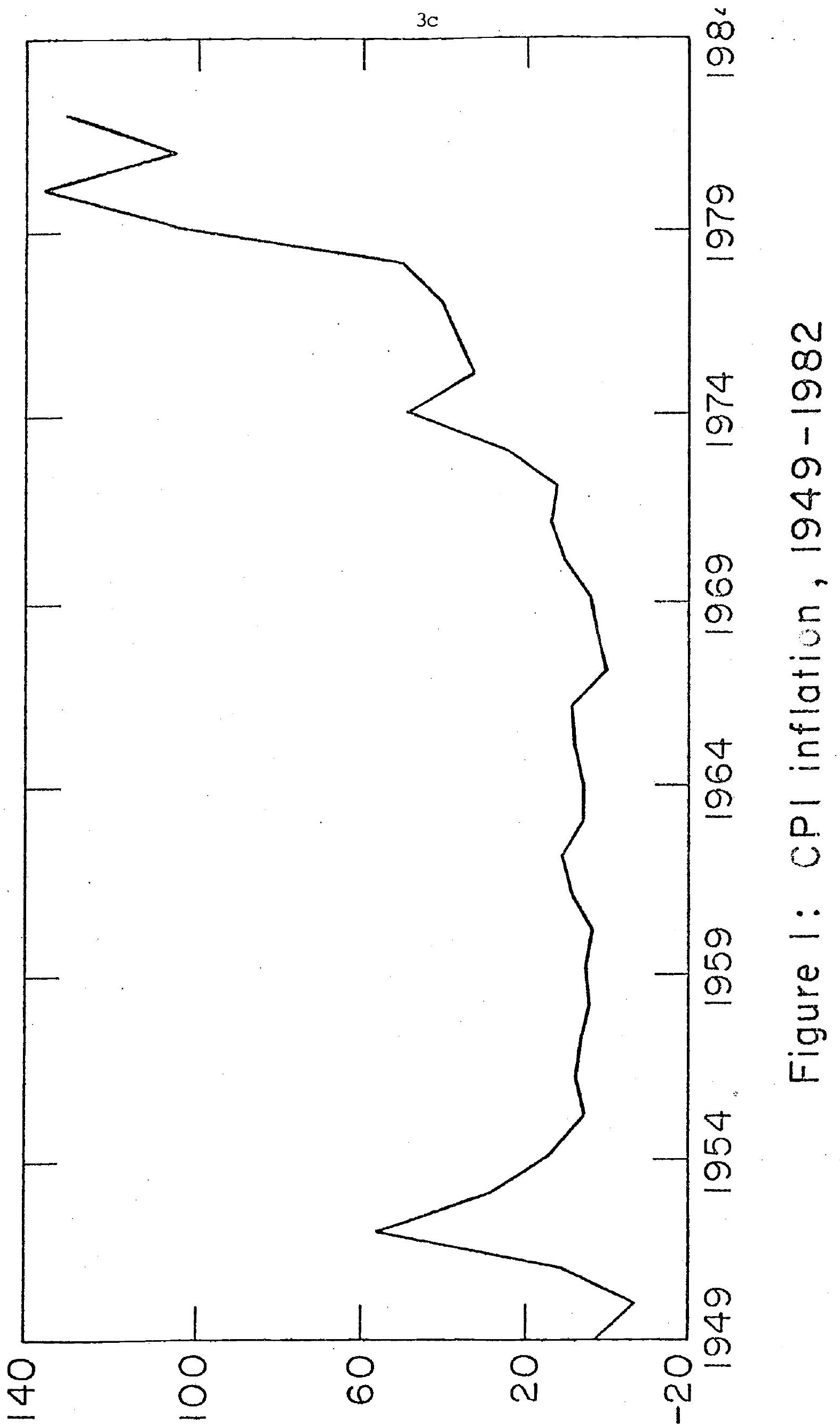


liabilities corresponding to most of the non-cquity financial assets owned by the private sector. The reserve requirement for the banks against foreign currency linked deposits is 90\%; and the indexation provided by private institutions is based on their holdings of government indexed liabilities. Thus the government's dominance in the allocation of resources extends to the capital markets; indeed, most private investment is financed with government assistance.

Wage indexation is included as part of the contract negotiated between the Histadrut (trade union organization) and the lanufacturers' Association. These azreements, typically biennial, cover most of the labor force. The frequency and details of cost of living adjustments have varied over the years. Currently the adjustments are made every three months, with compensation for inflation varying with the inflation rate. For instance, if the quarterly inflation rate is less than $20 \%$, there is $80 \%$ compensation for inflation; if the inflation rate is more than $30 \%$, compensation is $90 \%$. It is also agreed that ther: will be nego+iations between the Histadrut and the amployers if the real wage falls. 8

The Activities and Financing of Government: The government budget deficit reported in Table 3 for the years 1978-1982 is the total deficit on both internal and external account, as recorded in the IMF data, for fiscal years. Table 6 's more detailed budget data for * calendar year 1981 present a fuller description of the scope of government activity in the economy.$^{9}$

Note first that government purchases of goods and services, lines $(1+12)$ amount to $44 \%$ of GNP. The $44 \%$ includes $27 \%$ in defense spending, much of that abroad, and close to $6 \%$ that is investment spending. 10 
Table 6: Government Budget, 1981

$$
\text { ( } \% \text { of GNP) }
$$

I. Domestic

1. Purchases of goods and servicest

32.4

$\begin{array}{ll}\text { 2. Transfer payments } & 20.0\end{array}$

3. Subsidies $\quad 8.3$

4. Direct subsidization of credit ${ }^{3} \quad \underline{2.5}$

5. Total donestic expenditure 63.2

6. Taxes 45.0

7. Property and entrepreneuriel incone of public sector

8. Total doikstic receipts

9. Domestic deficit

10. Subsidy component of credit

11. Inflationary erosion of money base

II. Foreign

12. Net purchases abroad

13. Foreign income

Of which: U.S. government grants

6.6

14. Foreign deficit

15. Total deficit

$\times \quad 19.4$

Source: Bank of Israel Annual Report, 1931 (Hebrew edition), pp.101, 104. 


\section{Table 6 continued}

Notes: I Includes domestic defense spending equal to $15 \%$ of GNP.

2 Transfer payments include explicit interest payments: nominal interest on nominal bonds and real portion of interest on indexed bonds. Interest payments are close to $15 \%$ of GNP. Transfers are net of conpulsory loan redernptions.

${ }^{3}$ Actual disbursements.

${ }^{4}$ Calculated by Bank of Israel, as difference between nominal interest paid by borrowers and interest that would be paid at real rate of $4 \%$

${ }^{5}$ This is minly defense spending. Note that total government purchases of goods and services, $(1+12)=447$ of GNP, is well above the $33^{\%}$ recorded as goverament consumption in Table 1. The difference is accounted for by governinent investment activities, and by the fact that government consumption in 1981 was $39.1 \%$ of GNP.

6 Transfers to the national institutions, such as the Jewish Agency, equal to $2.1 \%$ of GNP, not recorded as foreign income of the government. 
Subsidies recorded in line 3 are for the purchase of gools and services.

In addition, the government provides extensive subsidies to borrowers, some recorded in line 4. However, the major subsidization of credit has occurred through the provision of low nominal interest loans; the Bank calculates the subsidy element in such credit durin's 1981 at nearly $7 \%$ of GNP. This amount is noted in Table 6 , but not included in any of the budget totals. The provision of low nominal interest rate credit since 1979 has been in the process of being phased out and replaced by indexed loans.11

The government finances its activities mostly through taxation. The largest revenue generators are the income tax and value added tax, which in 1981 raised $18.1 \%$ and $5.2 \%$ of GNP respectively. National insurance payments in 1981 were $7.7 \%$ of GNP. There is an impressive array of other taxes. In addition, as Table 6 shows, U.S. government grants provide a substantial proportion of the financing for government spending.

At this point, the logical step is to explain how the deficit of 19.4\% of GNP in Table 6 was financed in 1981, throush external borrowing, domestic borrowing in the form of both price level and exchange rate linked assets, and the creation of high-powered money. Regrettably data difficulties now become significant. The TMF presents the data contained in Table 7 a, for fiscal year 1981/2, which begins April 1. The deficit before foreign grants in that period was nearly $23 \%$ of GNP. Foreign grants and loans financed more than half of that amount. Domestic borrowing amounted to $10 \%$ of GNP, a large part of that from the Bank of Israel. The difference between entries 7 and 8 
Table 7a: Financing of Government Deficit, Fiscal Year 1980

$$
\text { (\% of GNP) }
$$

1. Government expenditure and net lending

72.7

2. Budget revenue

49.7

3. Foreign grants

4. Deficit to be financed

5. Net foreign borrowing

6. Net donestic bond issues ${ }^{2}$

7. Net credit fron Bank of Israel

15.3

8. Net impact on base money

6.7

Source: IInF.

1 Equal to loans of $10 \%$ of GNP minus repayments of $4.7 \%$ of GNP.

2 Equal to bond issues of $9.6 \%$ of GNP minus repayments of $3.4 \%$ of GNP. 
in the table is presumably a result in the differences in the tining with which transactions are recorded by the Treasury and actual payments. In fiscal year 1981, there was substantial use of Bank of Israel credit by the Treasury, more than in most earlier years.

Table $7 \mathrm{~b}$ presents Bank of Israel data on government finance. The data are much less clean than those of the IMF. The Bank does not present a comprehensive table on the financing of the government deficit, concentrating instead on financing of the domestic component of the deficit, defined as the deficit that arises from the government's activities in the domestic economy. As can be seen, there is a significant difference between the estimates of the domestic deficit in Tables 6 and $7 \mathrm{~b}$. Rather than dwell on these difficulties, I note that it appears that sales of both bonds and foreign exchange, in approximately equal amounts, provide most of the financing for the domestic deficit. Nonetheless, the increase in the money base accounts for the financing of a significant canponent of government spending-about $2.5 \%$ of GNP.12 Even though the monetary base in 1991 was under $3.5 \%$ of GNP, large amounts of revenue can be raised at high rates of inflation. ${ }^{13}$

Part $B$ of Table $7 \mathrm{~b}$ attempts to account for the foreign component of the deficit. The government sector borrowed heavily abroad, using the proceeds both to pay for government imports and to sell to domèstic residents. In this account too there remains a sizeable discrepancy, part of which may result from capital gains on the Bank of Israel's holdings of foreign reserves. Adding parts $A$ and $B$ of Table $7 \mathrm{~b}$, we find the general outlines confirm those of Table $7 \mathrm{a}$, which applies to fiscal year 1981. In both Table $7 \mathrm{a}$ and $7 \mathrm{~b}$ it appears that foreign and 
Table 7b: Bank of Israel Data on Financing of Government Deficit, 1981

$$
(\% \text { of GNP) }
$$

A. Dowestic deficit and financing.

1. Domestic deficit from Table 5

15.0

2. Errors and onissions

4.8

3. Domestic public sector deficit $1,2 \quad 10.2$

4. Net public sector lending

5. Sale of foreign exchange to dornestic rasidents

5.9

6. Sale of debt to private sector ${ }^{3}$

B. Foreign deficit and financing.

7. Foreign deficit from Table 6

$\underline{4.4}$

8. Public sector foreign borrowingst

7.1

9. Transfers of foreign currency via national institutions

10. Increase in reserves

0.6

11. Line 5 5.9

$\begin{array}{ll}\text { Net foreign currency acquisitions }(8+9-10-11) & 2.7\end{array}$

12. Errors and omissions (including capital gains on reserves)

Source: Bank of Israel Annual Report, 1981 (Hebrew), p.224.

1 Described in source as "Liquidity injection steming from public sector excess demand." 


\section{Table $7 \mathrm{~b}$ continued}

${ }^{2}$ Lines 3-6 follow the schene used by Shiffer (1982), Table 5, p.32. Line 3 in table is line 1 in source (noted above); line 4 is sum of lines $3 \mathrm{a}$ and $3 \mathrm{~b}$ in source.

${ }^{3}$ Calculated as resicual.

${ }^{4}$ Calculated from Table 7-1, ibid, p.150, lines $4 \mathrm{~b}$ and 6b, (in dollars) multiplied by average exchange rate for the year, from IFS data. 
domestic borrowing are of the same order of magnitude.

International Trade: Tables 8 and 9 present details of Israel's international transactions in 1981. The bulk of imports of goods is accounted for by intermediate products and by oil. A significant share of exports is accounted for by industrial goods; some of these are defense-related. The service account is large on both the import and export side, and is close to being balanced. Note that the balance on goods and services in 1981 was just less than gross investment. It can be said--though not accurately--that Israel's investment spending is financed from abroad.

Table 9 examines the financing of the current account deficit and details of aid. Unilateral transfers, governmental and private, cover most of the deficit on net goods and services account. Unilateral transfers to the government are Anerican government grants. About half a billion dollars is received by the national institutions, primarily the Jewish Agency, as a result of donations by world Jewry. Further unilateral transfers from indiriduals are made to the prirate suctor. German reparations continue at a level of close to a half billion dollars; these restitution payments are made directly to individuals.

Table 9 contains more detail on U.S. government aid. Before the 1973 war, U.S. aid was small. In 1973, emergency military aid amounting to more than $10 \%$ of GNP was provided, and total aid has remained at approximately that level since then. More than half the flow of resources from the U.S government in any one year is grants. The column "Net Loans" is the surn of new loans made within the year, minus interest and principal payments. This amount is expected to reach zero in 1983. 
Table 8: Current Account 19811

$$
\text { (\% of GNP) }
$$

Imports

70.3

Goods

44.5

(Defense

10.0)

Capital goods

4.7

Intermediate goods

28.0

(Of which oil

9.2)

Services

25.8

Exports

49.9

Goods

27.3

Industrial zood:

16.2

(excl. diamonds)

Services

22.6

Balance on goods

$-20.4$

and services

Private transfers (net)

5.0

Official transfers

8.3

Current account

Source: Bank of Israel Report, 1982.

1 In 1982 the balance on goods and servcies fell to $-22.5^{\%}$ of GNP, despite a reduction of $2.6 \%$ of GNP in net non-civilian imports. 
Table 9: Balance of Payments, 1981

( $\$$ billion)

\% of GNP

A. 1. Net goods and services

$-4.43 \quad 20.4$

Private sector

$-1.90$

Public

$-2.53$

2. Unilateral transfers

$2.89 \quad 13.3$

Private sector

1.09

Public sector

1.80

3. Net long and medium tern capital

movements

Private sector

$-.04$

Public sector

1.08

4. Net basic balance of payments

$-.50$

Private sector

$-.86$

Public sector

B. Unilateral transfers

Private sector

1.09

German reparations

.44

Individuals: imnigrants

.23

others

.27

Public sector

1.80

National institutions

Governmental

1.36 
Table 9 continued

C. U.S. Government Aid. ( $\$$ billions)
(1)
(2)
$(1)+(2)$

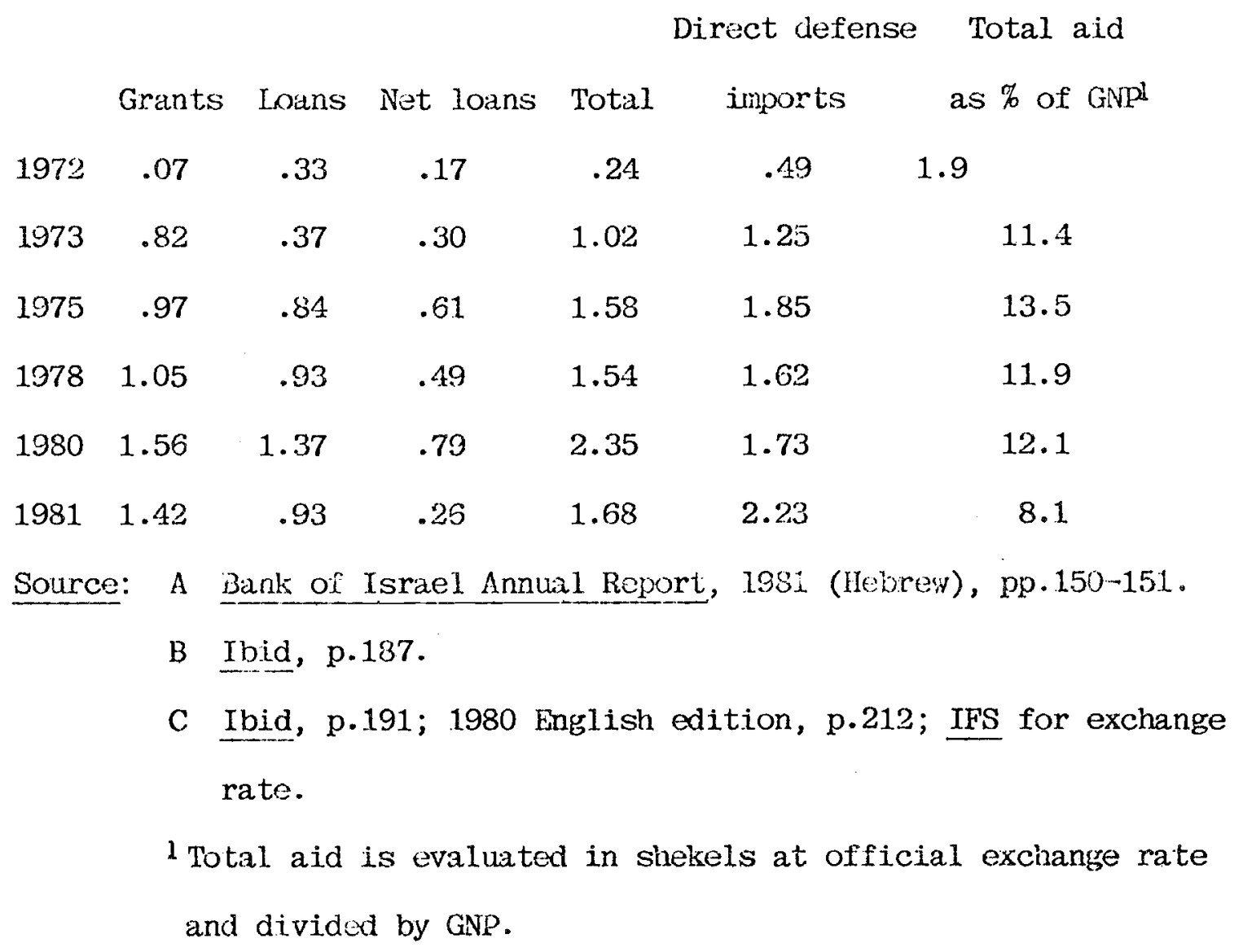


U.S. governmont aid is related to purchases of defense equirment in the U.S. Aid and defense imports are of the same order of magnitude, with defense imports typically slightly in excess of aid.

The exchange rate has since 1977 been on a very dirty float. The Bank of Israel intervenes in the market continuously, and occasionally attempts to stabilize the inflation rate by causing the exchange rate to appreciate. ${ }^{14}$ The reform of 1977 liberalized the capital account, permitting free capital flows and also the holding of foreign assets by domestic residents. ${ }^{15}$ Subsequently the authorities have intervened to affect capital movements. One inturvention took the form of a tax on capital imports, imposed in 1979 when donestic tight monetary policy raised interest raies and caused an undesired (by the authorities) capital inflow.

Monetary Policy: Monetary policy in Israel is constrained by two factors: first, real interest rates on index bonds are inflexible and determined legislatively; and second, political pressures make it difficult to allow the real exchange rate to move freely. Neither constraint is absolute. First, it is only the yield on new bonds that is fixed by legislation, and the Bank of Israel can intervene in the secondary market to attenpt to move the yield on bonds. In practice its interventions are directed chiefly to stabilizing the price of bonds. Second, the real exchange rate is sometimes allowed to change. 16

Given the constraints under which it works, the Bank has not in the recent inflationary period pursued money growth targets. It has pursued credit targets, by limiting the amount of credit banks can provide their customers. Strict credit targets and controls were in 
effect in 1979. At that time the tarsets were partially specified in Israeli currency terms, and partially in foreign curcency. This meant the nominal targets adjusted autonatically for exchange rate changes. But this was not the major hole in the credit constraint; it was instead the availability of subsidized export credits. Up to the time of the 1979 credit freeze and squeeze, the export credits had not been fully utilized. Once the credit controls came into effect, exporters took the full amount of export credit to which they were entitled, and provided trade credit to their customers. The private sector thus began to find ways around the Bank's credit constraints, as it typically does. Nonetheless, the 1979-80 period of restraint did significantly reduce the balance of payments deficit.

The Governor of the Bank of Israel is described by the law as the government's economic adviser, but there is no evidence that the advice that has been offered--which is typically to get the budget deficit under control--has been taken. The initiative for economic policy is with the Finance Minister, and the Bank has attempted to rux a restrictive policy only when the Finance Minister has so desired. This has been infrequently.

The Goals of Policy: Israeli policynakers have generally given first priority to reducing the balance of payments deficit. Concern over inflation has mounted in recent years, but has not been sufficient to induce tough anti-inflationary policies. There were in the 1970 's two major episodes of contractionary policy, in 1975-76 and 1979-80, each of which was aimed mainly at the balance of payments deficit, but with the implied effects on the inflation rate clearly being welcome. In both cases there was a significant reduction in the balance of 
payments deficit, but less effect on the inflation rate.

The liberalization of foreign exchange holdings in 1977 was

follorved a year later by the transition to triple digit inflation. The role, if any, of the liberalization in the increase in the inflation rate will be discussed below.

The most ambitious attempt to reduce the payments deficit and the inflation rate was undertaken in 1979 by a newly appointed finance minister, who directed his efforts at reclucing the budget deficit, partly through freezing governinent employment and partly through removing purchase subsidies. At the same time, the Bank of Israel was to constrain credit growth. The policy began to work by increasing unemployment in early 1980, the balance of payments deficit narrowed, but there was no quick impact on the inflation rate. The restrictive policies were extremely unpopular, and with an election expected, the finance minister was replaced by the present minister.

The new minister argued that supply side policies would reduce the inflation rate, and claimed $t$, ir $x_{i}$ lement them by reducing import tariffs and increasing subsidies. In the judgment of political observers, the policies were successful at turning around an election that had seemed lost by the government. There has been no subsequent sign that the government is willing or interested in reducing inflation if there is a price-in terms of forgone output--to be paid.

The prolonged period since October 1982 during which the real exchange rate has been appreciating as part of an anti-inflationary policy is unusual in that the balance of payments goal of policy has been sacrificed to the inflation goal. The preference for attempting to stabilize inflation by manipulating the exchange rate without 
pursuing other contractionary policies reflects the general unwillingness of policy-makers in the period since 1973 to stabilize the inflation rate by reducing aggregate demand and causing unemployment.

\section{Model}

In this section I outline a descriptive model of the Israeli econony based on the post-1977 strucutre of the financial system, that I believe captures the rain mechanisms in the operation of the economy. The model is presented both as an attempt to provide a concise description of the economy, and because it is used in section III to guide the discussion of the causes of the current inflation and possible methods of reducing the inflation rate.

The Structure of the Model.

The Assets liarkets: There are four assets: money; domestic price level (CPI) indexed bonds; foreign currency denominated securities; and equity claims to the returns on physical capital. Honey is dencminated in shekels and pays no interest. In the model assume all money is a government liability; we thus omit inside shekel-denominated deposits. ${ }^{17}$ Index bonds are liabilities of the government. We assume linkage is $100 \%$, although formally some bonds have less than complete linkage. ${ }^{18}$ physical capital (or the equity claims on capital's returns) is assumed to be a perfect portfolio substitute for index. bonds. 19

Israeli residents may hold both foreign securities and domestically issued exchange rate linked securities. In form, the latter are bank liabilities but because the reserve requirement against such deposits is $90 \%$, we treat them as a liability of the government. 
The government pays interest on the reserves held against the foreign currency linked securities.

We postulate the following asset market equilibriun conditions:20

$$
\begin{array}{ll}
\frac{M_{t}}{p_{t}}=L\left(y_{t}, R_{t}^{B}, R_{t}^{F}, V_{t}\right) ; \quad L_{1}>0, L_{2}<0, I_{3}<0, L_{4}>0 \\
\frac{B_{t}}{p_{t}}+q_{t} K_{t}=K\left(y_{t}, R_{t}^{B}, R_{t}^{F}, V_{t}\right) ; & K_{1}<0, K_{2}>0, K_{3}<0, K_{4}>0 \\
\frac{e_{t}}{p_{t}}\left(F_{t}^{a_{t}}+F_{t}^{f}\right)=J\left(y_{t}, R_{t}^{B}, R_{t}^{f}, V_{t}\right) ; & J_{1} \geqslant 0, J_{2}<0, J_{3}>0, J_{4}>0 \\
r_{t}^{B}=\frac{F_{K}\left(K_{t}, v_{t}\right)}{q_{t}}+\frac{t^{a_{t}+1}-q_{t}}{q_{t}} ; \quad \frac{\partial F_{K}}{\partial K_{t}}<0, \frac{\partial F_{K}}{\partial y_{t}}>0 \\
v_{t}=\frac{M_{t}}{p_{t}}+\frac{B_{t}}{p_{t}}+q_{t} K_{t}+\frac{e_{t}}{p_{t}}\left(F_{t}^{f}+F_{t}^{d}\right)
\end{array}
$$

The appendix lists symbols in the order in which they appear.

Equations (1) through (3) are suppiy equals dernand conditions for the real money stock, real assets (bonds plus capital) and foreign assets respectively. The stock budget constraint ensures that the three equations are linearly dependent. The assets are assuned to be gross substitutes.21 
An increase in output increases the demand for money for transactions purposes and therefore must, by the stock budget constraint, reduce the demand for at least one of the other assets. Since foreign-currency linked deposits are sometimes used as medium of exchange, we assune that the dernand for bonds and capital falls when the level of output rises, while the effect on the deanand for foreign currency linked securities of a rise in output is allowed to be cither positive or negative. The demand for each asset increases with wealth.

Equation (4) states that the expected real yield on capital is equal to the real yield on index bonds. This condition reflects the assumption that the two assets are perfect portfolio substitutes. The marginal product of capital is assumed to decrease with the capital stock and increase with the level of output.

The Goods Market: There is a single domestically produced good, with aggregate supply function:

$y_{t}^{s}=\phi\left(p_{t}, w_{t}, e_{t} p_{t}^{f}, F_{t}\right) ; \quad \phi_{1}>0, \phi_{2}<0, \phi_{3}<0, \phi_{4}>0$

The supply function is hornogeneous of degree zero in $p$, w, and ep $f$

Aggregate denand for domestically produced goods is:

$$
\begin{gathered}
y_{t}^{d}=\psi\left(v_{t}, y_{t}, \frac{e_{t} p_{t}^{f}}{p_{t}}, q_{t}, K_{t}, G_{t}, T_{t}\right) ; \quad \psi_{1}>0,1>\psi_{2}>0, \psi_{3}>0, \psi_{4}>0, \\
\psi_{5}>0, \psi_{6}>0, \psi_{7}<0 .
\end{gathered}
$$

Real exchange rate depreciation increases the demand for domestically produced goods. So does an increase in $\mathrm{q}$, which increases investment demand.22 For any given $q$, investment demand increases with the capital stock, so that increases in $K$ increase aggregate demand, given 
weal.th. ${ }^{23}$ Finally, fiscal policy, as medsured by government spending on domestically produced roods and services, and taxes (net of transfers) affect aggregate demand for donestic goods.

Wage Setting: The rate of increase of the noninal wage is in part determined by indexation, with past inflation rates determining present rates of nominal wage increase. In addition, the rate of wage increase is affected by expectations of inflation and deviations of output from the full einployment level, and by deviations of the real wase fron its equilibrium level.

$$
\begin{aligned}
\frac{w_{t}}{w_{t-1}}= & a_{1}\left(\frac{p_{t-1}}{p_{t-2}}\right)+\left(1-a_{1}\right)\left(\frac{t-1 p_{t}}{p_{t-1}}\right)+a_{2}\left(t_{t-1} y_{t}-y_{t}^{*}\right)+a_{3}\left(\left(\frac{w_{t-1}}{p_{t-1}}\right)^{*}\right. \\
& \left.-\left(\frac{w_{t-1}}{p_{t-1}}\right)\right)
\end{aligned}
$$

The term following the coefficient $a_{1}$ represents the effects of indexing: actual past inflation affects today's rate of wage increase. So too does anticipated inflation, to an extent that depends on how much compensation will occur through indexation. Indexed wase adjustments in practice take p?.ace every three months.

The third term on the right hand side represents the pressure of demand on the wage. When output is expected to be above the full employment level, $y^{*}$, wages $r i s e$ more rapidly.

When there has been unanticipated inflation in the past, with the coefficient $a_{1}$ less than unity, some catch-up of real wages will öcur. These catch-ups occur mainly at the bargaining over base wages between the Histadrut (Labor Federation) and the employers. We represent them 
in the model by including a term in $\left((w / p)^{*}-(w / p)\right)$, the difference between the equilibrium or full employment real wage and the actual real wage. The catch-up term makes it more difficult for accelerating inflation permanently to reduce the real wage. There is accordingly rocm for real wages to be affected by the dynamics of the inflation process. Because this last term adjusts the wage on the basis of the difference between actual and full employment wages, it does not represent "real wage resistance," a phenomemon which could be added. Equation (3) is of course a Phillips curve.

The Government Budget Constraint: The government purchases goods both at home and abroad, and finances itself by taxation, money issue, donestic security issues, foreign burroving, and foreign aid. The governinent budiget constraint is:

$$
\begin{aligned}
& \frac{M_{t+1}-M_{t}}{p_{t}}+\frac{B_{t+1}}{p_{t}}+\frac{e_{t}}{p_{t}}\left(F_{t+}^{d}-R S_{t+1}\right)+\frac{e_{t}}{p_{t}} F A_{t} \\
& \quad=G_{t}-T_{t}+\frac{e_{t}}{p_{t}} G_{t}^{F}+\left(1+r_{t-1}^{B}\right) \frac{B_{t}}{p_{t-1}}+\frac{e_{t}}{p_{t}}\left(1+r_{t-1}^{F}\right)\left(F_{t}^{d}-R S_{t}\right)
\end{aligned}
$$

The assumption marle in ( 3 ) $x$ : the timing of sransactions is that, for example, new indexed debt that will become the initial stock of debt next period $\left(B_{t+1}\right)$ is sold in the current period at the current price level. The right hand side includes interest payments on the debt and on foreign borrowing. The fact that the debt is indexed may be seen by noting that the real amount paid on the debt, $\left(1+r_{t-1}^{B}\right) \frac{B_{t}}{p_{t-1}}$, is independent of inflation. 
The Foreign Sector:

$$
\begin{gathered}
\mathrm{Nx}_{t}-\frac{\mathrm{e}_{t} \mathrm{G}_{t}^{\mathrm{F}}}{\mathrm{p}_{t}}+\frac{\mathrm{e}_{t}}{\mathrm{p}_{t}}\left(1+\mathrm{r}_{\mathrm{t}-1}^{\mathrm{f}}\right)\left(\mathrm{F}_{t}^{\mathrm{f}}+R S_{t}\right)+\frac{\mathrm{e}_{t}}{\mathrm{p}_{t}} F A_{t} \\
=\frac{e_{t}}{p_{t}}\left(F_{t+1}^{f}+R S_{t+1}\right)
\end{gathered}
$$

Net exports of the private sector minus governinent imports plus interest receipts (in practice these are negative) and aid from abroad are equal to the acquisition of foreign dssets by the private and government sectors together. The current account is of course deeply in deficit, which results in the increasing foreign indebtedness of the economy .

Net exports are a function of aggregate demand and the price of domestic relative to foreign goods:

$$
N X_{t}=g\left(\frac{e_{t} p_{t}^{F}}{p_{t}}, y_{t}^{d}\right) \quad g_{1}>0, g_{2}<0
$$

Factor Supplies: The capital stock is given by:

$$
K_{t+1}=(1-\delta) K_{t}+I\left(q_{t}, K_{t}\right)
$$

population and effective labor force are taken to be exogeneous, and growing at rate $n$. This assumption rules out one significant constraint on policymakers: the belief that any prolonged period of unemployment would reduce the rate of immigration and increase emigration. 
Short Run Equilibrium

Within each period, beginning of period stocks, $M_{t}, B_{t}, K_{t}, F_{t}^{f}$, $\mathrm{F}_{t}^{\mathrm{d}}$, and $\mathrm{RS}_{t}$, are given. The nominal warre, $w_{t}$, is predetermined. The interest rate on foreizn assets, $r_{t}^{f}$, and the foreign price level, $p_{t}^{f}$, are exageneous to the Israeli economy. In discussing the determination of short run equilibrium we take expectations (of the price level, relative price of capital, and the exchange rats) as given.

The Assets Markets: Equilibrium in the assets markets can be studied using equation ( $x$ ) and any two of equations (1) - (3). The aim is to show the asset rnarket equilibrium values of $q$ and $e / p$ conditional on values of the price level and output, along with the stock and expectational variables. We will examine the properties of the functions that express asset market equilibrium conditions:

$$
\begin{aligned}
& q_{t}=q\left(x_{t}\right) \\
& e_{t} / p_{t}=h\left(X_{t}\right) \\
& x_{t} \equiv\left[p_{t}, y_{t}, M_{t}, B_{t}, K_{t}, F_{t}, \frac{t^{p_{t+1}}}{p_{t}}, \frac{t^{e} t+1}{e_{t}}, \frac{t^{q_{t+1}}}{q_{t}}, R_{t}^{F}\right]
\end{aligned}
$$

Figure 2 shows equilibrium loci for the money (LL) and bonds (BB) markets. In drawing these loci, the level of output, $y$, is taken to be constant, as are the other variables in the vector $X$ defined in (15). From equation (4), for given $k_{t}$ and $y_{t}, F_{K}$ is constant, so that $q$ and $r^{B}$ are, frorn (4), inversely related given $k_{t}, y_{t}$, and $\frac{t^{q_{t+1}}}{q_{t}}$.

The LL locus in Figure 2 is negatively sloped because an increase in $\mathrm{q}$ causes an excess demand for real balances through both wealth and 
rate of return effects. The excess demand has to be offset by a reduction in $e / p$, reducing real wealth, to maintain equilibrium. In the bond-capital market, whose equilibrium is shown by the BB locus, an increase in q causes excess supply which is offset by an increase in demand induced through an increase in the real exchange rate. Also shown in Figure 2 is the FF locus (equation (3)), which is positively sloped and steeper than the BB locus. Asset market equilibrium obtains at point $E$, with corresponding equilibrim values of the price of installed capital (and the real interest rate) and the real exchange rate.

We now show graphically how chinges in the price level and the level of output respectively affect the equilibriun values of $q$ and e/p. In Figure 3 , an increase in tine price level creates an excess demand for real balances, thus shifting the LL curve to the left, to L'. The increase in the price level creates an excess supply of bonds, shifting $B 8$ to the right, to $B^{\prime}$. Clearly, q falls. The effects on the real exchange rate appear ambiguous. However, the real exchange rate must fall, because both a rise in the price level and decline in q create an excess supply of foreign clurrency denominated assets, which is removed by a fall in the real exchange rate. Thus the new equilibrium at $E^{\prime}$ shows both $q$ and $e / p$ lower as a result of the rise in the price level.

In Figure 4 we present a similar analysis of the effects of an increase in the level of output. This simultaneously raises the transactions demand for money and the marginal product of capital. For given $q$, the real interest rate rises. The net effect on the demand for real balances is ambiguous, but we assume it to be positive. 


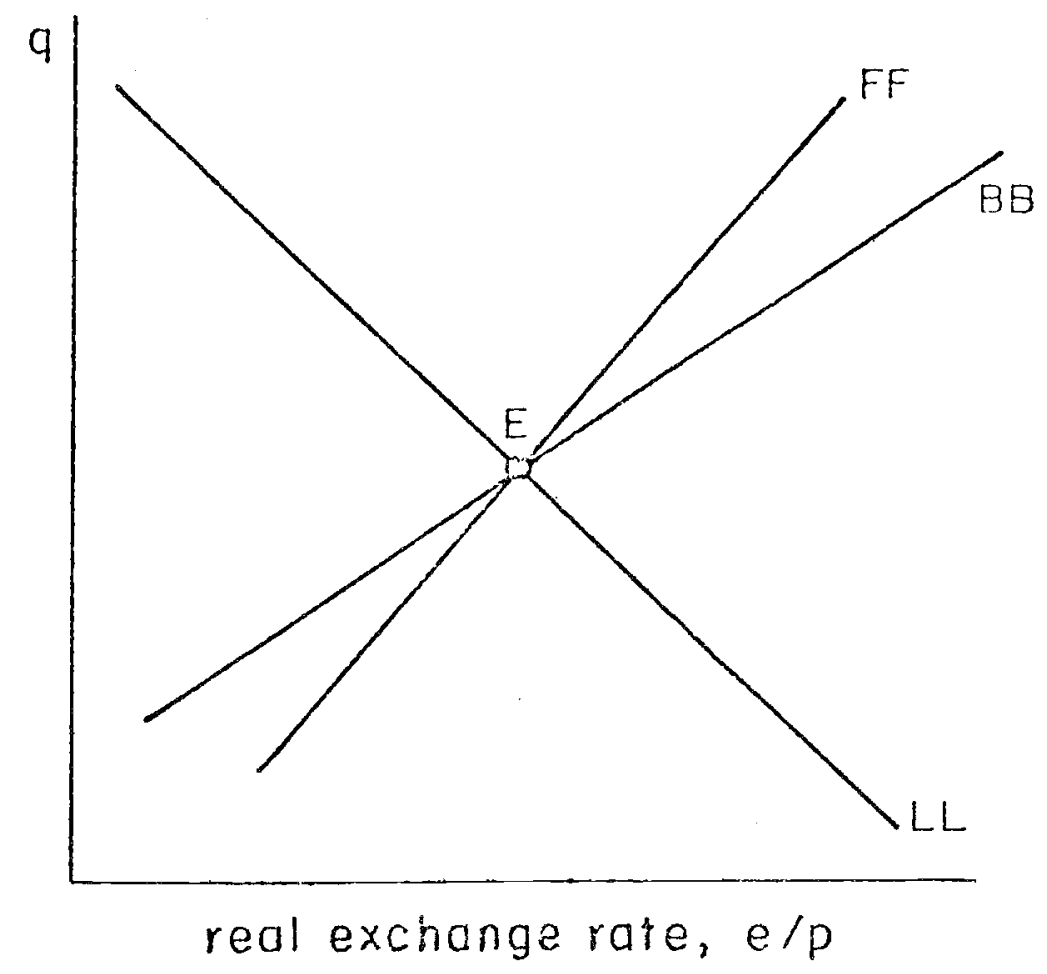

Figure 2: Asset Market Equilibrium.

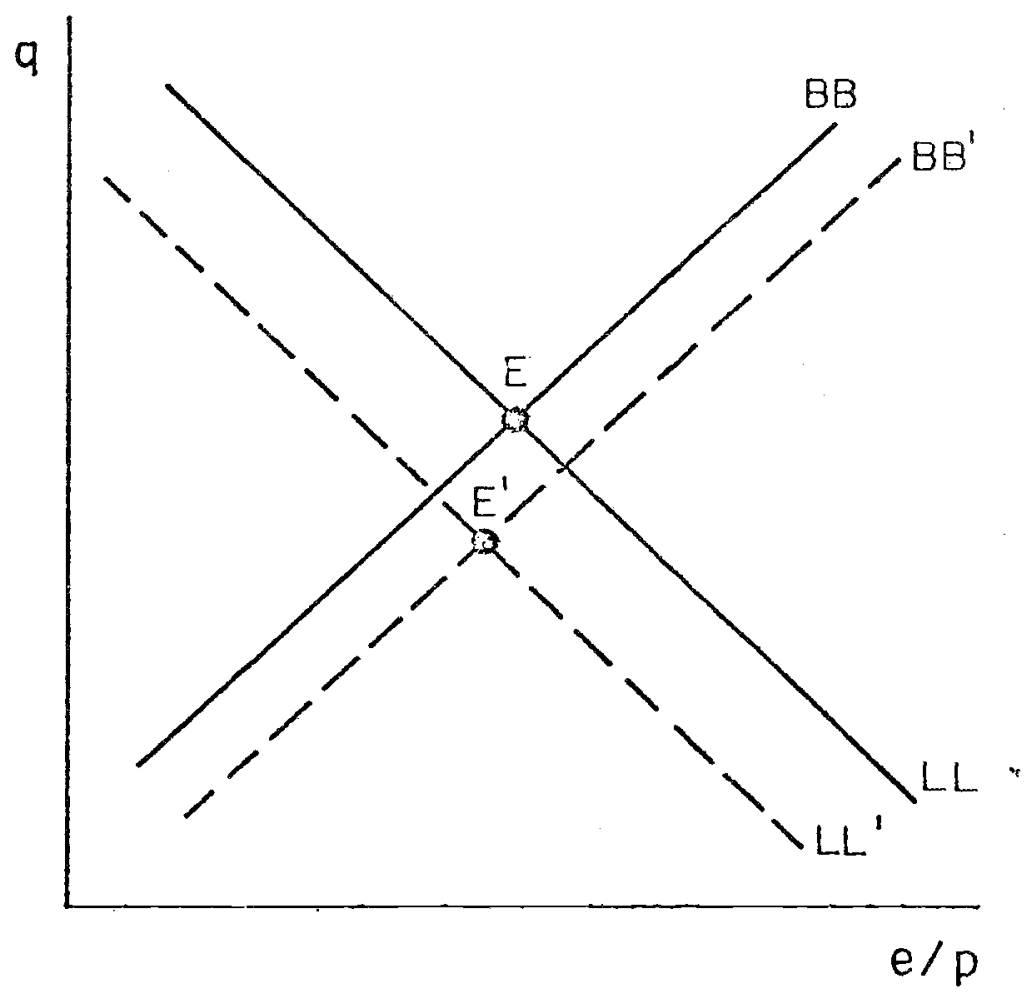

Figure 3: The Effects of an Increase in the Price Level on Asset Market Equilibrium. 
Accordingly, the LL curve shifts to the left, to LL'.

In the market for foreign currency denominated assets, the increase in output has an uncertain effect on demand through the transactions variable, and reduces demand through the rate of return variable. We assume denand falls, thus shifting the FF curve in Figure 4 to the left, to $\mathrm{FF}^{\prime}$. The real exchange rate falls. The effect on $\mathrm{q}$ is uncertain. The transactions demand related effects tend to cause a to $\mathrm{fall}^{24}$ while those associated with the increase in the marrinal product of capital tend to cause $q$ to rise. We assume the effect is typically positive.

The partial derivatives of the function in (13) and (14), obtained similarly, are:

$\frac{\partial q}{\partial p}>0, \frac{\partial q}{\partial y}>0, \frac{\partial q}{\partial M}>0, \frac{\partial q}{\partial B}<0, \frac{\partial q}{\partial K}<0, \frac{\partial q}{\partial F}=0, \frac{\partial q}{\partial \frac{t^{p_{t+1}}}{p_{t}}}>0$

$\frac{\frac{\partial q}{t^{e} t+1}}{e_{t}}<0 \quad \frac{\partial q}{\frac{t^{q} t+}{q_{t}}}>0, \frac{\partial q}{\partial f^{f}}<0$

$\frac{\partial h}{\partial p}\left\langle 0, \frac{\partial h}{\partial y}\left\langle 0, \frac{\partial h}{\partial M}>0, \frac{\partial h}{\partial B} ?, \frac{\partial h}{\partial F}<0, \frac{\partial h}{\partial \frac{t^{p_{t+1}}}{p_{t}}} ?, \frac{\partial h}{\partial \frac{t^{e} t+1}{e_{t}}}>0\right.\right.$

$\frac{\partial h}{\partial \frac{t^{q_{t+1}}}{q_{t}}} ?, \frac{\partial h}{\partial R^{f}}>0$ 


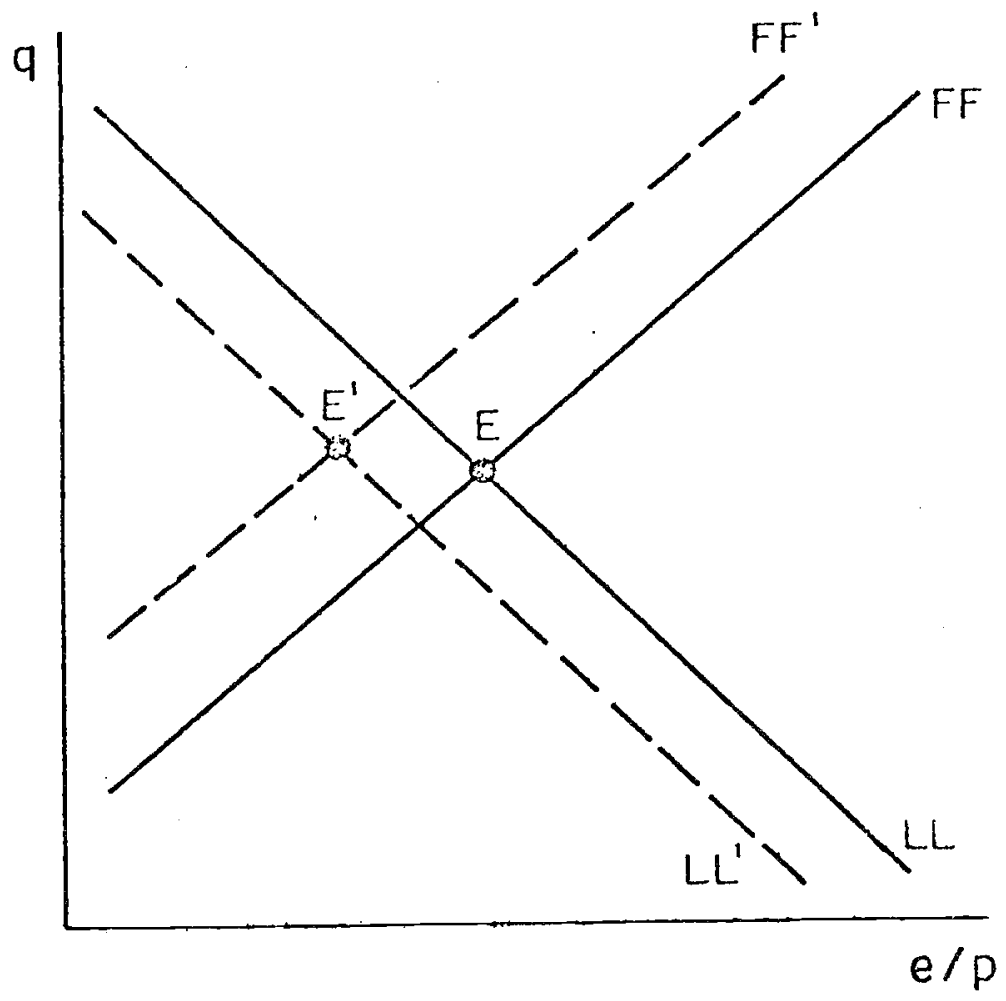

Figure 4: The Effects of an Increase in Output on Assets Market Equiiibrium. 
Although a change in the stock of bonds has an uncertain effect on the real exchange rate that clears the assets markets $\left(\frac{\partial h}{\partial B}\right.$ is of uncertain sign), an open market purchase (increasing $M$ while reducing B) increases e/p. In other words, expansionary monetary policy causes the exchange rate to depreciate. A swap of domestic for foreign currency denominated bonds, increasing $B$ while reducing $F$, reduces $q$ and increases e/p. This open market operation corresponds to sterilized intervention in the foreign exchange narket.

Under the assumption that bonds and capital are perfect portfolio substitutes, an open market swap of bonds for capital can have real effects only if the return on capital differs depending on whether it is held by the goverment or the private sector. For instance, if the government buys capital and takes it out of production, the marginal product of capital rises. As a result, $q$ rises but the effects on the real exchange rate are uncertain.

Goods Market Equilibrium: Equilibrium obtains in the goods market when the output of domestic goods, $y_{t}^{s}$ from (5), is equal to the demand for those goods, $y_{t}^{d}$ from (7). In Figure 5 we show aggregate supply and demand curves in $(p, y)$ space. 25

The curves shown in Figure 5 have the conventional slopes. However, in the case of aggregate supply, there are countervailing effects. The slope of the aggregate supply curve is:

$\left.\frac{d p}{d y}\right|_{A S}=\frac{1-\phi_{3} h_{2}}{\phi_{1}+\phi_{3} \frac{\partial e}{\partial p}}$

With both $\phi_{3}$ and $h_{2}$ negative, the numerator need not be positive. The 
ambiguity arises because an increase in output increases the transactions demand for money, thereby causing a currency appreciation through the assets markets, and a reduction in production costs. We assume this effect is not large enough to cause the AS curve to be negatively sloped.

On the aggregate demand side, all the channels through which an increase in the price level affect aggregate demand operate in the same direction: an increase in the price level reduces aggregate demand. We assume that an increase in output creates an excess supply of gools, despite some ambiguities arising from asset market effects of an increase in output. 26

The intersection of the aggregate denand and supply curves determines the price level and domestic output. Given expectations, the foreign interest rate, and the stock variables, the joint equilibrium of the assets and goods markets determines the price level (p) and output $(y)$, the exchange rate $(e)$, the relative price of installed capital $(q)$, and the rea? interest rate $\left(r^{B}\right)$.

The exchange rate is accordingly determined by the interaction of the goods and assets markets, without direct reference to the external sector. But of course expectations of future exchange rates and the levels of stocks of foreign assets affect the current exchange rate, so that there is no useful sense in which it can be said that the exchange rate is determined uniquely in the assets markets, or that it is not influenced by the current account.

Comparative Statics.

We now examine the effects of changes in asset stocks, fiscal variables, and expectations on the equilibrium price and output levels. 
We start by considering the impact effects of an increase in the money stock, holding expectations constant.

An Increase in the Money Stock: An increase in the money stock increases both $\mathrm{q}$ and $\mathrm{e} / \mathrm{p}$ in the assets markets. The goods market effects are shown in Figure 5. The depreciated real exchange rate and the rise in $q$ both increase aggregate demand, shifting the $A D$ curve to $\mathrm{AD}^{\prime}$. The higher exchange rate shifts the AS curve to $\mathrm{AS}^{\prime}$. The price level and level of output both increase. ${ }^{27}$

One source of the short run non-neutrality of money is the fact that the nominal wase is pre-determined. But there is a second source of non-neutrality, which has so far been concealed by concentrating on the goods and assets markets. The government budjet constraint implies that a money stock increase has to be accompanied by some other policy change. 28 For instance, the change could be an increase in governinent spending, or cut in taxes. In this case, output and prices would rise by more than would result purely from the increase in the money stock.

An Open Market Purchase: An open market purchase of bonds has the same qualitative effects as are shown in Figure 5 . Both $q$ and $e / p$ rise in the assets markets, shifting the aggregate demand and supply curves as shown. Both output and the price level rise.

In discussing such an operation, we assume that expectations of inflation, of the rate of change of the exchange rate, and of the rate of change of $q$, do not change. But given the change in the composition of the government debt, expectations will adjust. These effects are discussed below.

The Effects of an Anticipated Depreciation: An anticipated depreciation of the exchange rate makes foreign exchange denoninated 


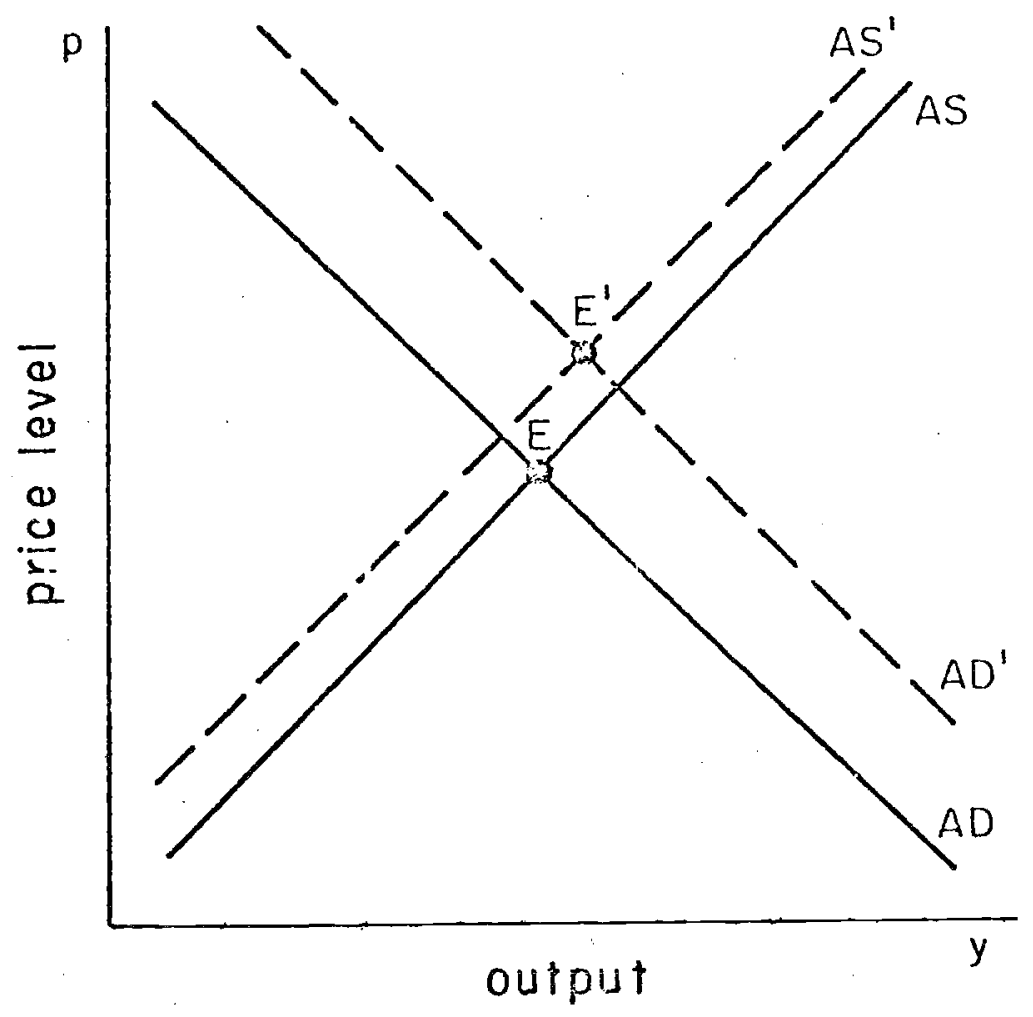

Figure 5 : Goods Market Equilibrium, and the Effects of an Increase in the Money Stock. 
securities more attractive relative to domestic, and tends to reduce $q$ and increase $\mathrm{e} / \mathrm{p}$ in the assets markets. Investment demand falls while the demand for Israeli exports rises. The net effect on aggregate demand is therefore uncertain. If the export effect dominates, both the price level and output rise.

The Effects of an Incrase in the Wage Rate: An increase in the wage rate shifts the aggregate supply curve up and to the right, raising the price level and reducing output. The relative price of installed capital, $q$, probably falls, while the effects on the real exchange rate are uncertain.

Currency Liberalization: The modelling of the currency liberalization in the current rodel requires some care. Foreign currency denoninated securities were traded before the liberalization, but there was no free access to foreign capital markets. Foreign exchange purchased through this market was typically at a prenium over the official rate. Modelling the operation of such a system would recilire the introduction of a new variable, rupresenting the premium for foreign-currency linked securities over the official exchange rate. ${ }^{29}$

We do not explicitly model the pre-existing structure of the capital markets. Rather, we view the currency liberalization as an increase in the yield available in the capital markets on foreigncurrency denominated securities. The effects of such a change are already implied by (17) and (18): in the capital markets there is an increase in the real exchange rate (a depreciation) and a fall in $q$. The effects on aggregate demanrl are thus uncertain, since the fall in $q$ reduces demand while the depreciation increases it. The depreciation 
in addition shifts up the aggregate supply curve.

The above discussion assunes that asset stocks and expectations remain unchanged. In the model with which we are working, it is entirely possible in the short run and ignoring expectations, for both the exchange rate and $q$ to be kept at desired levels through open market operations. It would have been possible through open market swaps of foreign exchange denominated assets for money and bonds for the grovernment to maintain both $q$ and $e / p$ at their pre-liberalization levels. Had this been done, there would later have been budgetary implications resulting fran the substitution of interest-bearing assets for money in the portfolios of the public that would have increased the inflation rate. Moving over to the yoods markets, the only effects of the liberalization in the current period would have been a result of changed expectations about future budget deficits or values of $q$.

The liberalization thus need not have created any major short-run disturbances to the economy except--and this is a major exceptionthrough expectaicions. But the liberalization a.s carried out did affect the goods markets directly. The liberalization was accompanied by the removal of tariffs and export subsidies and by a $50 \%$ devaluation that was intended to maintain the effective exchange rate fixed. Assuming the effective exchange rate unchanged, the supply curve would not have shifted as a result of the devaluation. But because there were preexisting foreign currency denoninated assets, the 50\% devaluation had a large wealth effect, shifting up the asgregate demand curve and causing the price level to rise. There was thus an immediate expansionary effect from the liberalization-cum-deraluation.

In addition, and not less important, the liberalization by causing 
a shift into foreign currency denominated securities from domestic money reduced the dornestic currency denominated money base and thus required higher rates of inflation to produce the same amount of revenue from seignniorage.

The External sector: The trade account is completely determined within each period by the level of output and the real exchange rate. The service account is pr@determined. An open market purchase that causes a depreciation and expansion of output has ambiguous effects on the trade account: the real depreciation tends to increase net exports while the rise in domestic income tends to decrease net exports.

A fiscal expansion (not studied above) unambiguously increases the current account deficit.

Long Run Constraints: Suppose the economy is in a steady state, with given ratios of real balances to bonds and government issued foreign currency liabilities. These ratios can be assumed to be determined by monetary policy:

$\mathrm{b}=\lambda_{1} \mathrm{~m}$

$f^{d}=\lambda_{2} m$

where $b \equiv \frac{B}{p N}, m \equiv \frac{M}{p N}, f^{d} \equiv \frac{e F^{d}}{p N}$.

Lower case letters without time subscripts are steady state real values of the equivalent upper case symbols.

Substituting into equations (9) and (10), we obtain the steady state government budget and balance of payments constraints:

$$
\begin{aligned}
& m(\pi+n(1+\pi))+b(1+\pi)\left(n-r^{B}\right)+\left(f^{d}-r s\right)\left[\left(1+\pi^{f}\right)\left(n-r r^{f}\right)\right]+f a \\
& \quad=g-\tau+g^{f}
\end{aligned}
$$


where $\tau$ is per capita real government revenue from taxes net of transfers..$^{30}$

The balance of payments constraint is:

$f a+n x=g^{f}+\left(f^{f}+r s\right)\left(1+\pi^{f}\right)\left(n-r r^{f}\right)$

The crucial point about these constraints-and a well-known oneis that the amount of seigniorage and the possibility of issuing other assets to finance a budzet deficit (in (22)) depends significantly on the growth rate of the economy. In a rapidly growing economy, the government can finance a budget deficit through the printing of money without creating inflation. When the rrowth rate is lower, it takes a higher inflation rate, if indeed the budget deficit can be financed at al1. 31

Sirnilarly, the relationship between the growth rate of output and the real interest rate is an important determinant of whether a deficit in either the government's account or the foreign trade sector can be financed through borrowing against bonds or foreign exchange. If growth is rapid-as it was in Israel up to 1972--there is no difficulty in having large budget deficits financed by households wanting to acquire assets that will maintain the asset to income ratio constant. But when growth is slow and the interest, rate above the growth rate, borrowing generates ever increasing burdens on the budget over time.

$$
\text { Inflationary Issues. }
$$

In this section we briefly analyze issues of general interest that arise from the Israeli inflationary experience. The Inflation Tax.

Table 10 presents data on the amount of revenue obtained by the Israeli government through the creation of high powered money. The 
period during which seigniorage revenue was at a maximum was 1970-1974, when the economy was growing fast (at least into 1973), and when the inflation rate was, by later standards, low. The ratio of high powered money to income was during that period at about $12 \%$, roughly the ratio that was maintained from 1955 until the implementation of the liberalization in 1977 . Table 10 shows a sharp reduction in the ratio of monetary base to income-which is the base of the inflation tax-starting in 1979. This shift followed the liberalization with a lag. The lag is probably a reflection of the fact that it took time until foreign currency deposits began to be used as means of payment, thereby producing the shift out of domestic currency.

Is it possible that the current amount of seigniorage-about $2 \%$ of GNP-could be obtained at a lower inflation rate? In other words, is the economy on the slippery side of the Laffer curve? That obviously depends on the inflation elasticity of the demand for the monetary base. If the ratio of base to income returned to $10 \%$, then an inflation of about $17 \%$ (plus $3 \%$ for growth) would generate revenue equal to $2 \%$ of GNP.

There are two ways of producing such a shift. First, it could happen if the inflation rate were reduced in the current postliberalization institutional setting. That would require a very large elasticity of the monetary base with respect to inflation-an elasticity that is not at all visible in the data in Table 10 for the pre-reform years.

Second, such a shift could be induced by undoing the currency liberalization. The demand function for high powered money could be shifted by policy measures, such as that recently implemented that 
imposes a tax on the purchase of foreign currency. Even so, because financial sophistication has increased rapidly since 1977 , it is doubtful that the system would return to a base to income ratio of $10 \%$, nearly double the current U.S. ratio.

Thus a reduction in the inflation rate would have to be accompanied by a reduced reliance on seigniorage by the government. Is the Inflation Tax Negative? It is often asserted that the inflation tax in Israel is negative. Table 11 shows the calculation: the tax on the holdings of monetary base is more than offset for the private sector by the fall in the value of its nominal liabilities to the government. The point made by the table is that a marginal $1 \%$ of inflation increases private sector wealth. The effect was at a maxinum in 1979 and is gradually becoming less important as the government stops providing non-indexed loans to the private sector.

Table 11 shows that the real balance effect would be negative in Israel. That is, if economic agents regard their liabilities to the government as liabilities, then their wealth woil. increase when the price level increases. It does not necessarily follow that an increase in the money stock would produce negative revenue for the government. 32 An increase of one shekel in the money stock would in the first instance provide one shekel's worth of resources to the government. The subsequent negative effects, summarized in Table 11 , would have to be deducted from the initial positive effect. But it does appear from the table that the effect through subsidized credit is so large-or was so large until recently--that an increase in the money stock would have reduced the present discounted value of government revenue.

This of course brings to the fore the basic question about the 
Israeli inflation: why does the government persist in policies that produce such high rates of inflation? With notining obviously gained by continuing inflation, why not stop it? We return to this question below.

The Balance of Payments and the Foreign Debt.

The balance of payments has been the major precccupation of Israeli policymakers for the past three decades. Figure 6 and Table 12 show net exports for the period since $1950 .{ }^{33}$ The foreign deficit has been in the range of $20 \%$ of GNP for most of the period, with a sharp increase taking place following the Yom Kippur Var and associated oil shock.

As noted by kirni(1979), there are two standard arguments for the case that the large import surplus is undesirable. The first is that the accompanying accumulation of foreign debt places an undue burden on future generations. The second is that the magnitude of the deficit and the need to rely on external financing, some of it in the form of grants, makes for excessive vulnerability to outside pressure, econonic and political.

Table 13 presents data on the extent of the external debt. The gross debt passed the $\$ 20$ billion mark in the third quarter of 1982 . The net debt at the end of 1982 was equal to $63 \%$ of GNP or 1.4 times the value of exports. With a real interest rate of $5 \%$, the annual interest cost of the debt would be above 3.0\% of GNP. This would be a manageable amount in steady state. But the ratio of the net foreign debt to GNP is growing because of the size of current account deficits financed through borrowing. By the end of 1982 net debt service amounted to nearly $25 \%$ of exports and more than $10 \%$ of GNP. 
Table 12: Foreign Trade

\begin{tabular}{|c|c|c|c|}
\hline Exports & Imports & $I M-X$ & Real exchange ratel \\
\hline GNP & GNP & GNP & \\
\hline
\end{tabular}

$\begin{array}{crrrl}1950-53 & 6.0 & 27.2 & 21.2 & 100 \\ 1954-67 & 17.6 & 37.7 & 20.1 & 216.7 \\ 1968-73 & 30.6 & 53.5 & 22.9 & 266.5 \\ 1974-77 & 37.2 & 66.9 & 29.7 & 232.8 \\ 1978-81 & 48.7 & 70.6 & 21.9 & 246.8 \\ 1982 & 44.7 & 67.0 & 22.3 & 254.7\end{array}$

${ }^{1}$ Calculated as ratio $\frac{e p^{*}}{p}$ where e is $\$$ exchange rate, $\mathrm{p}^{*}$ is U.S. price level (GNP deflator) and $p$ is Israeli price level (GDP deflaior). There was extensive licensing of imports in the period to 1954.

Table 13: Israel's External Debt

(End of period)

$\begin{array}{lrrrr}\text { 1. Gross external debt } & 10.2 & 16.4 & 24.2 & 25.2 \\ \text { 2. Net external debt } & 6.7 & 11.1 & 13.1 & 13.7 \\ \text { 3. Net debt as \% of GNP } & 57.1 & 66.4 & 63.1 & 62.9 \\ \text { 4. Net debt as \% of exports } & 175.6 & 151.5 & 113.2 & 140.7 \\ \text { Source: IMF. } & & & & \end{array}$

$\$$ billion

$1975 \quad 1979 \quad 1981 \quad 1982$


Is the accumulation of the dobt desirable, or at least better than the alternatives $?^{34}$ Note first that part of the import surplus of the last eight years has been associated with defense imports. Figure 6 includes data on defense imports, which show that most of the significant increase in the import surplus in the mid-70's was defense related (the rest was oil). Borrowing wuld be optimal if the current defense burden mere transitory. But if the current rate of defense spending were to continue, it would become necessary to curtail borrowing. 35

The concern over vulnerability to foreign pressure resulting from the import surplus and the magnitude of the foreign debt is a real one. It is also a very old concern. (See Halevi and Klinov-lialul (1968)). Such pressures have been brought to bear in the past, though the abrupt cut-off of aid that has been the primary fear of policymakers has not happened. If it were to happen, the access of the Israeli government and private sector to international capital markets would be curtailed; there would be major disruption to the economy and. a reduction in the standard of 1iving.

At least for this reason, successive Israeli governments have sought to bring about a reduction of the import surplus. ${ }^{36}$ The level of exports has risen rapidly relative to GNP, as Figure 6 and Table 12 show. The economy succeeded in moving resources into the export sector through a variety of incentives, including subsidized export credits, and recently, exchange rate insurance. Although the level of imports has risen along with exports, and the basic $20 \%$ of GNP import surplus remains, the private sector import surplus has been reduced-defense imports have risen as a share of GiP. 


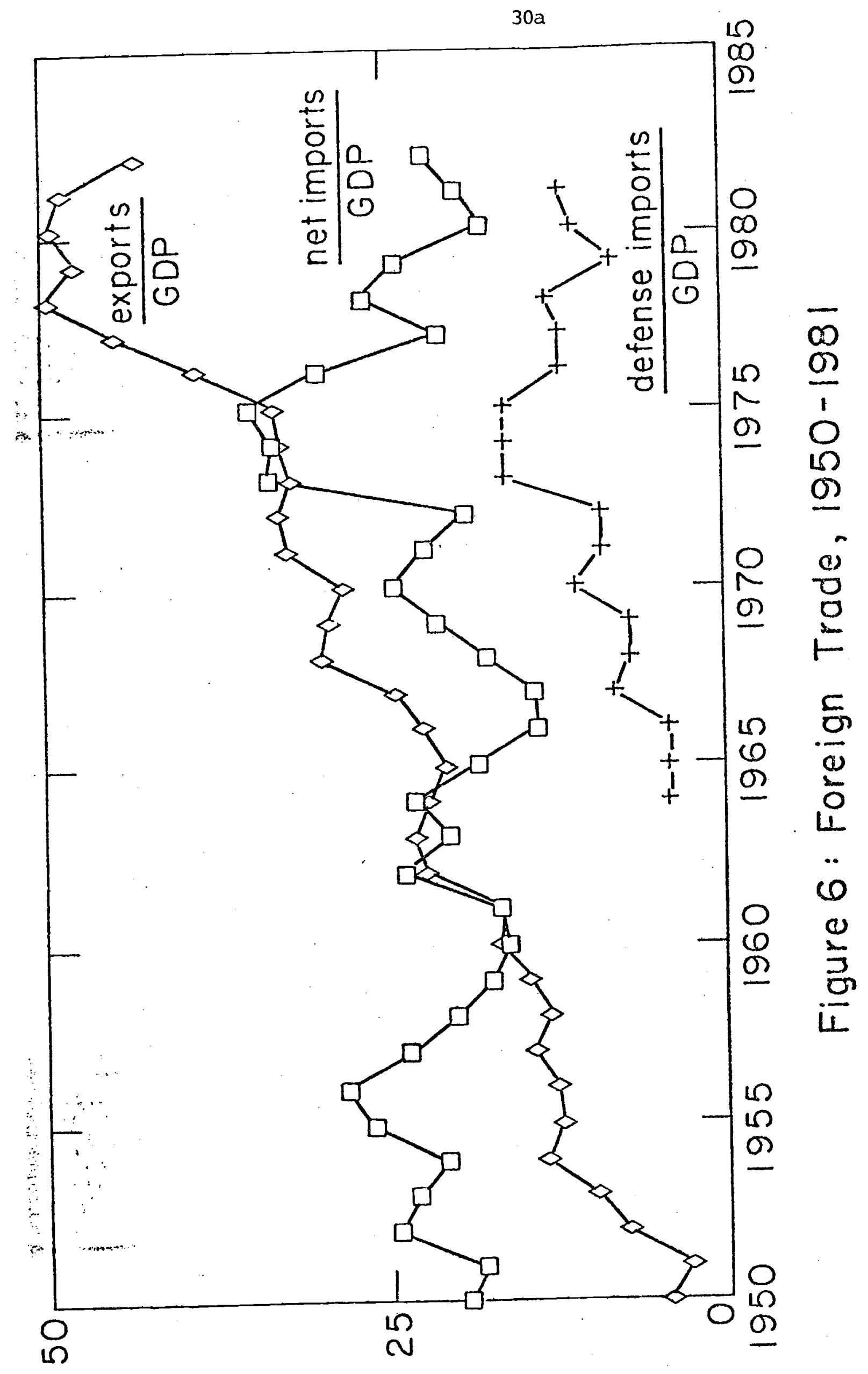


The Israeli government has three times undertaken major restrictive policies to reduce the balance of payments deficit. The first period was 1965-67, which shows in Figure 6 as having the lowest import surplus of the entire period. After the 1973 war, there was again a period in which taxes were raised and the balance of payments deficit was reduced. The latter episode took place against a background of high inflation. So did the attempted 1979-80 program to reduce the payments deficit through restrictive fiscal and credit policy. In each case there was a reduction in the payments deficit, at the cost of higher unemployment. The conclusion, especially after the painful 1965-67 episode, was that it was preferable to attempt to improve the balance of payments gradually, excepi in extrene circumstances like those after 1973 when the import surplus moved close to $40 \%$ of GNP.

It has generally been believed that to achieve its eventual aim of a substantially reduced current account deficit, the government will have to produce a continuing slow real devaluation. Whether a real devaluation is needed, though, depends on relative productivity trends in Israel and abroad. It appears from Table 12 that the government has had some success in achieving a real devaluation over the years, althoush the data should be treated with extreme caution; in any event, the success of the policy can also be gauged by its effects on the* volume of exports and the import surplus. Taking defense imports into account, this aspect of policy has been successful.

The 1982-83 policy that attempts to stabilize the inflation rate by causing a real appreciation has, however, sharply increased the balance of payments deficit and foreign borrowing. This policy is 
undoing the reduction in the external deficit that was painfully achieved during the past decade. With an external deficit in excess of $\$ 4$ billion per year, projected by sorne estimates to rise further in 1983, the prospects for a rising and ultiritely unsustainable external debt burden become high. For this reason the current policy will be reversed.

Inflation and Other Trends in the Israeli Economy.

The economy described in the first part of this paper is very different from the Israeli economy in, say, 1960. In that year government expenditure was less than 30\% of GNP, the government budget deficit (IFS definition), was $4 \%$ of GNP the CPI was $2 \%$ higher than in the previous year; only the import surplus, at $18 \%$ of GivP, was at a modern level. It was the import surplus that was the main cause of the restrictive fiscal and monetary policies that produced the 1966-67 recession, which as we have seen in Figure 6 did improve the current account. The question is, what happened after 1960 ?

Table 14 presents summary data for the behavior of the major macroeconanic variables over subperiods since 1958, and Figure 7 shows some of the same variables graphically. The period up to 1967 looks tranquil from today's perspective. Growth was rapid, inflation low, and government spending and the budget deficit low. After the 1967 war there was an apparently permanent jump in the level of government spending, due largely but not entirely to higher defense spending. For the next four years the economy grew rapidly, absorbing labor from the administered territories and immigration. (Bruno, 1983). The increase in the labor force permitted rapid growth without pressure on the real wage. By 1973 the pressure of demand began to affect the inflation 


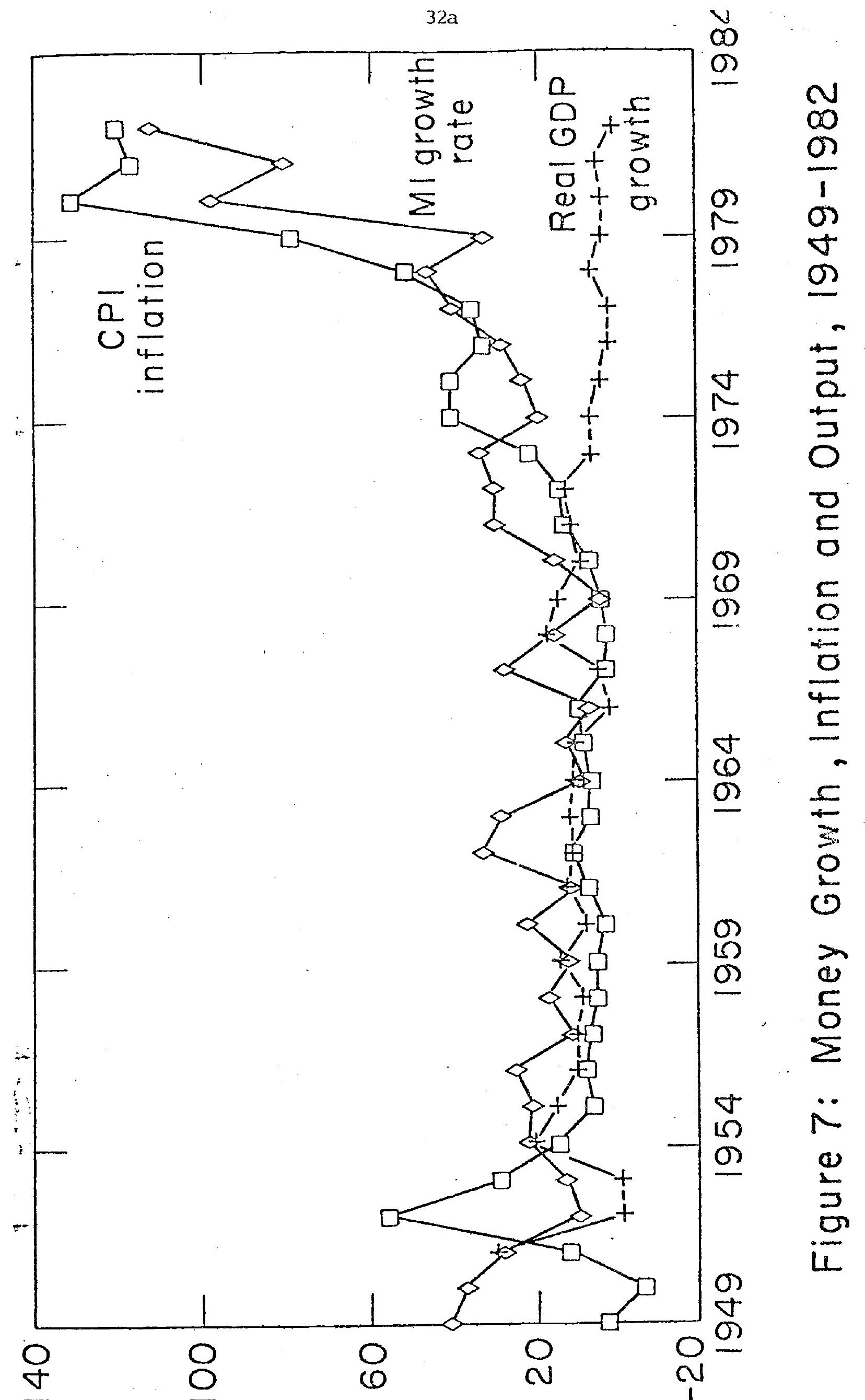


Table 14: Major Macroeconomic Variables, 1958-1981

$\begin{array}{lllllll}\mathrm{ml} & \mathrm{p} & \mathrm{y} & \overline{\mathrm{GE}} & \mathrm{GR} & \mathrm{DEF} & \mathrm{GD} \\ \overline{\mathrm{GNP}} & \overline{\mathrm{GNP}} & \overline{\mathrm{GNP}} & \overline{\mathrm{GNP}}\end{array}$

$\begin{array}{rrrrrrrr}1958-67 & 16.1 & 5.4 & 8.5 & 32.21 & 28.0 & 4.2 & 10.6 \\ 1968-72 & 17.1 & 8.0 & 11.1 & 47.1 & 32.2 & 14.9 & 21.8 \\ 1973-77 & 27.4 & 35.9 & 2.7 & 64.2 & 42.5 & 21.7 & 30.0 \\ 1978-81^{2} & 60.8 & 95.6 & 1.8 & 61.3 & 45.3 & 16.0 & 25.2\end{array}$

Source: IFS for columns 1 to 6; Bank of Israel Annual Report, 1981

(Hebrew), p.85, last column; also Patinkin (1970), p.69.

lower case letters indicate growth rate

141 is $M 1$

$\mathrm{p}$ is CPI

$y$ is real GDP

$\mathrm{GE}$ is government expenditure

GR is government revenue

DEF is government deficit. (IMF definition)

$\mathrm{GD}$ is defense expenditure

1 Data are ratios of fiscal year (starting April 1) government variables to calendar year GNP.

2 Columns 4 through 6 in this row are for $1978-80$. 
rate, which reached $20 \%$ even before the Yom Ki.ppur War.

Then in 1973 the oil and war shocks struck. Defense spending jumped by nearly $10 \%$ of GNP once again. The supply shock both reduced the growth rate of output and caused a rapid rise in the inflation rate in 1974. In that year the government made a deal with the Histadrut to forgo one round of indexation of wages, which made it possible to reduce the real wage and appeared to start the inflation rate back down towards the $20 \%$ level from which it had come in 1972. Taxes were raised and credit restricted to reduce the balance of payments deficit and inflation. From 1973 to 1977, GNP grew slowly. Productivity growth was negative in each of the years 1975-1977. The balance of payments deficit did fall.

The high levels of governnent (especially defense) spending and money growth continued. The inflation rate came down from its 1974 level, but appeared to stabilize at about $30 \%$ just as it currently appears to be stable at a higher rate. The government was taking about $3 \%$ of GNP in seigniorage, less than it lud taken in the three years before 1973. But as shown above, with the low real growth rate, a higher inflation rate was necessary to produce the same amount of seigniorage. Recall at this point that the real interest rate was kept fixed, so that any amount of the deficit that could not be covered through bond sales at the existing interest rate automatically fed into either an increase in the stock of high powered money, or the foreign deficit. Indexation made the inflation tolerable, and there was no willingriess to pay the price in terms of unemployment to reduce the inflation rate significantly.

Then cane the liberalization of 1977. As noted above, the 
liberalization was accompanied by a devaluation that produced a wealth effect in the goods market, thereby raising the price level and thus in the short run the inflation rate. With a lag, the liberalization also produced a shift in the demand for shekel denominated currency. The initial reaction was to move largely from index bonds to foreign currency linked deposits, thus not yet shifting the demand for local currency denominated money. It was only gradually that it was understood that the foreign currency balances could be used to make transactions, and the denand for shekel denoninated assets therefore shifted. Accordingly we see in Figure 7 that it is only in 1979 that there is a large increase in the inflation rate, accompanied by a fall in the growth rite of the money stock. Subsequeutly there is again a reasonably close correspondence between the inflation rate and the growth of M1.

Because the jump in the inflation rate came at a time when the growth rate of $M 1$ was not high, there has been a tendency in Israel to describe the inflation as being caused by a "buhble", meaning that it is due to unemplained sources rather than monetary pressures. But given the shift in the demand for shekel denominated assets, the inflation rate would at some point have had to exceed the growth rate of money.

But why then has the inflation rate not come down subsequently? There has not been a reduction in the growth rate of the nominal aggregates since the inflation rate broke through the triple digit range by the end of 1979. At one level this failure to reduce the growth rate of noninal money may be attributed to the need for revenue from seigniorage. But because during this period government revenue 
fron inflation was probably negative in the sense defined at the beginning of this section (see Table 10), the inflation has also to be blamed on a set of operating procedures (a constant real interest rate, reasonably constant real wages, exchange rate targets) that made the rate of growth of money endogeneous. From this viewpoint, the continued rapid inflation can be blamed rather on the government's failure to reduce its budget deficit. The large government deficit ensures that after all other sources of financing of the deficit have been tapped (foreign and domestic borrowing), the residual is financed by the printing of money.

Along with the higher inflation since 1973, the Israeli economy has also experienced much slower growth than before. part of the decline in the growth rate is a result of slower accumulation of factors of production (Bruno, 1983) and part a result of a fall in productivity growth. The heavy pressure of defense and government spending has resulted in a reduction in investment spending, and the labor force has been growing slowly. But productivity growth has fallen more rapidly in Israel than in other countries. The reason for this is not clear, though doubtless some blame attaches to the high inflation that has moved resources into the financial sector. 37

Stabilization Policy: The model presented above indicated that there is nothing particularly mysterious about the operation of either monetary or fiscal policy in a heavily indexed economy like the Israeli one, with its unusual menu of assets. Restrictive monetary or fiscal policy will reduce the price level or inflation rate. But they will also reduce the level of output.

The indexation formulae for wages do not provide instant price 
flexibility. There is a lag in the adjustment of wages, which means that the real wase would be high during the course of a disinflation. The one way out of this dilemna is an agreement with the Histadrut on a wage and macro-policy package. Such an agreement was successfully reached with the government in 1974 , when it was necessary to have a real devaluation and labor was persuaded to forgo indexation temporarily. In the absence of such an agreenent, it will take the pressure of unemployment to drive down the rate of wage increase and thus the rate of price increase. Israeli governments have not since the sixties shown evidence that they are willing to have prolonged unemployment. The choice is thus between a package, and attempts to disinflate gradually. In either case, the goverament would have to reduce its domestic deficit, to be sure that it would not end up again relying on money printing to finance the deficit.

The government has experimented with the alteruative of trying to reduce the inflation rate by keeping the prices of comodities or the exchainge rate stable. Such policies have not worked. Fixing $u_{i}$ the exchange rate for a period during which domestic inflation is continuing only ensures that a big correction has to take place later. Similarly, the attempt to use subsidies to stabilize some nominal prices leads to large increases in the budget deficit, and eventually to the lifting of the subsidies and more inflationary pressure.

There is one final question. The inflation rate is not a major issue in Israel. It is talked about, but there is no groundswell of public insistence that the rate be reduced. Indexation of pensions, long term savings, and wages, cover most of the difficulties that would face an unsophisticated economic agent living in an economy with a high 
and variable rate of inflation. The question is: why disinflate?

Israeli policymakers frequently assert that unemployment that would be needed to disinflate successfully cannot be justified in Israel. The 1965-67 recession during which unemployment reached double digits and there was net emigration has burned as deep a concern about unemployment in the memory of policymakers and the public as the Great Depression did in the United States.

The arguments for undergoing the pain of disinflation have not been established. It has frequently been asserted that the low growth of the seventies in Israel is a result of the high and variable inflation, which draws resources into non-productive activities like banking, and which distorts the price mechanism. But the productivity slowdown is a worldwide phencmenon, which has taken place in low inflation as well as hirg inflation countries. A convincing demonstration that it is indeed the inflation that is responsible for low growth would make the case for disinflation. 


\section{Footnotes}

${ }^{1}$ Un luss otherwise noted, data are from International Financial

Statistics or the IFS tape.

2 Kravis, Heston and Summers (1978) present estimates of Israeli per capita GDP adjusted for purchasing power differences that are around 60\% of the United States level for the years 1970, 1973, and 1974. The exchange rate mediated comparison for those three years ranged from $40 \%$ to $60 \%$.

${ }^{3}$ A similar table is presented in Shiffer (1982); his data differ slightly from those in rable 1 , apparently as a result of data revisions.

4 Berglas (1983).

${ }^{5}$ For accounts of Israeli indexation see Brenner and Patinkin (1977) and Kleiman (1977).

${ }^{6}$ In 1982 the banks were encouraged to offer high nominal interest rate time deposit accounts to increase the denand for nominal assets. At the same time, the tax treatment of nominal interest was adjusted to ensure only real interest was taxed. Accordingly the share of non-M1 nominal assets rose from $1.3 \%$ to $2 \%$ of financial assets. In April 1983 a $1 \%$ tax was imposed on the turnover of foreign currency linked assets, also with the aim of increasing the denand for shekel denominated assets.

7 Total net wealth of the non-financial private sector for the end of 1981 was estimated by the Bank of Israel to be a little above 4 times. GNP (Bank of Israel Annual Report, 1981, Hebrew edition, p.257): the housing stock and value of plant and equipment account for most of the excess of net wealth over financial wealth as recorded in Table 5 . 
${ }^{8}$ The less than 100\% compensation for inflation was introduced on the grounds that nominal wages should not be adjusted in response to external shocks. The lack of full indexation has led to continuing attempts by labor to restore real wages in inid-contract, and thus to increased labor strife. Some Israeli economists now argue that wage indexation should be complete, frequent, and put in place as soon as possible following each change in prices-on the grounds both that this would minimize labor trouble and that it would help the disinflation process.

${ }^{9}$ I am indebted to Zvi Auerbach for his assistance in compiling Table 6 and to Zalman Shiffer for advice on Table 7.

10 The Bank of Israel data differ in several respects from those of the IMF, which are based on Treasury calculations. The two sets of data are difficult to reconcile, in part because Bank data are typically for calendar years and Treasury data for fiscal years. The underlying sources of the difficulties appear to be the use by the Bank of a cash basis for expencitures and receipts as compared rith a less clear set of Treasury conventions on the timing of expenditures and receipts; and a wider definition of the government sector by the Bank. 11 The estimate for 1982 is $5.1 \%$ of GNP; the peak, in 1979 , was $11.3 \%$ of GNP.

12 The wide definition of the base is used in Table $7 \mathrm{~b}$. Continuing" the discussion fron footnote 10 , it is believed that the errors and anissions recorded in line 2 of Table 7b, which is based on monetary data as opposed to the budgetary data that underlie Table 5, result from: the difference between accrual (Table 6) and cash (Table 7b) accounting; from the treatment of interest; and perhaps from the 
treatment of government support of housing investment. The difference is unusually large in 1981.

13 During 1981, the change in the money base amounted to $2.4 \%$ of GNP (calculated from Bank of Israel Report, 1981 (Hebrew) p.251). However, since Bank of Israel profits are included in government revenue, this item is not shown separately in Table $7 \mathrm{~b}$.

14 It has been enzaged in such an exercise since october 1982, with the result that the real exchange rate has appreciated over $30 \%$, with no. visible effect on the inflation rate. A large devaluation is expected as of the time of rriting (July 1983).

15 For a description and evaluation of the reform, see Susisman (1979).

16 See Fischer (1981) for a discussion of monetary policy in Israel.

17 In 1973 the ratio of monetary base to $M 1$ was 93\%; at the end of 1981 the ratio was $78 \%$. The ratio of reserve money to GNP (expressed at an annual rate) wh $3.3 \%$ in the fourth quarter of 1981 . The eqdivalent ratio for the United States was $5.5 \%$ in 1982 .

$18 \mathrm{~A}$ bond with return that is $80 \%$ index linked can, at high rates of inflation, be viewed as a fully linked bond paying real interest at a rate equal to $80 \%$ of the stated real rate.

19 Given that the Israeli tax system is more inflation proof than the U.S. system this assumption is more appropriate for Israel than it would be for the U.S. There were nonetheless until 1981-2 major inflation-related distortions in the Israeli tax system. 20 'The asset menu and equilibrium conditions in this model are similar to those in the valuable paper by Fraenkel (1979). 
${ }^{21}$ An alternative formulation would have the real returns on each asset, measured in CPI units, in the demand functions. The present formulation is a specialized version of that form.

22 It has been suggested that because government intervention in the investment process is so pervasive, it might be preferable to treat investment as exogenous.

${ }^{23}$ This argument is based on an adjustment (of capital) cost function of the form $\mathrm{K} . \mathrm{C}(\mathrm{I} / \mathrm{K})$ where $\mathrm{I}$ is the rate of investment.

${ }^{24}$ This can be seen more clearly by adding the BB curve to the figure. ${ }^{25}$ These curves embody the assumption of asset market clearing, since the functions $q()$ and $h(),(13)$ and (14), are used to substitute for $\mathrm{q}$ and $\mathrm{e} / \mathrm{p}$ wherever they appear in (6) and (7).

26 These ambiguities arise only because an increase in output is assumed to increase $q$, thereby increasing demand both through a wealth effect and by raising investment. However, as noted in the discussion of Figure 4, this effect is assumed to be small. 27 The graphical analysis raiser the possibility that the suypl ${ }^{r}$ side exchange rate effect could lead to a fall in output when the money stock rises. This possibility can be ruled out by noting that if the price level were to rise in the same proportion as the money stock, with output at its original level, the assets markets would be in equilibrium, the derand for goods would be at its original level, but supply would exceed demand.

${ }^{28}$ In a more detailed model, an 1,1 money stock increase could result from a change in reserve requirements that would not necessarily affect the government budget. 
${ }^{29}$ Such a variable would perform for foreign currency linked securities a role almost identical to that of $q$ for capital: the value of the stock of such assets (the left hand side of the market clearing equation) would reflect the prenium; the interest component of the return would be reduced because of the higher cost of the asset; and expectations of changes in ; the premium would affect the expected return on the asset.

30 The presence of the $(1+\pi)$ and $\left(1+\pi^{f}\right)$ terms with $b$ and $\left(f^{d}-r s\right)$ respectively is a result of the assumption that the initial stock of bonds in period $t$ is sold at the end of period $t-1$.

${ }^{31}$ See Melnick and Sokoler (forthcaning) for calcualtions of the effects of reductions in the growth rate of the economy on the inflation rate when inflation is used to generate government revenue. 32 This issued is discussed in Fischer and Frenkel (1981) and in an MIT B.S. thesis by David Lebow (1983).

33 The balance of payments problem is discussed by Halevi and KlinovValul (1968), Michaely (1975), ard Karni (1979).

${ }^{34}$ Edi Karni points out that much of external borrowing during the seventies was at negative real rates.

35 Defense imports overstate the defense burden on the balance of payments, since it is doubtful Israel would be exporting arms if it were not for the defense burden of the past. 36 Wichaely (1974) describes the methods used to affect the baliance of trade and payments. He also calculates effective real exchange rates, which show little change over the period 1955-71.

37 This point has been emphasized by Jacob Frenkel. 
Appendix: Symbols

$u_{t}$ shekel denominated money stock.

$\mathrm{p}_{\mathrm{t}} \quad \mathrm{CPI}$ price level

$y_{t}$ real output

$\mathrm{R}_{t}^{B} \quad$ expected nominal return on index bonds

$R_{t}^{F}$ expected nominal return on foreign currency linked bonds (in dometic currency)

$V_{t} \quad$ real wealth

$\frac{B_{t}}{p_{t}}$ real stock of index bonds

$\mathrm{q}_{t} \quad$ relative price of installed capital

$K_{t} \quad$ physical capital stock

$e_{t}$ exchange rate

$\mathrm{F}_{\mathrm{t}}^{\mathrm{f}}$ holdings by domestic residents of foreign-issued foreign currency bonds (measured in foreign currency)

$\mathrm{F}_{\mathrm{t}}^{\mathrm{d}}$ holdings by domestic residents of domestically issued foreign currency bonds (measured in foreign currency)

$r_{t}^{B} \quad$ real yield on index bonds

$\mathrm{F}_{\mathrm{K}}$ marginal product of capital

$w_{t}$ wage rate

$G_{t}$ domestic government purchase of goods and services

$\mathrm{T}_{\mathrm{t}}$ net taxes

$\mathrm{RS}_{\mathrm{t}}$ reserves

$\mathrm{FA}_{t}$ foreign aid, (measured in foreign currency)

$G_{t}^{F}$ government purchases abroad (measured in foreign currency) 
$r_{t}^{f}$ noininal interest rate on foreign currency bonds (measured in foreign currency)

$\mathrm{NX}_{t}$ net exports

$\pi$ domestic inflation rate

$\pi^{f}$ foreign inflation rate

$\mathrm{rr}^{\mathrm{f}}$ real interest rate on foreign currency bonds (measured in donestic goods)

rs per capita reserves (measured in real terms)

fa per capita foreign aid (measured in real terms)

$\mathrm{g}^{\mathrm{f}}$ per capita governinent purchases abroad (measured in real terms) 


\section{Bibliography}

Berglas, E.

(1983) Defense and the Economy: the Israeli Experience, Falk Institute, Jerusalem, Discussion Paper 83:01.

Brenner, R., and Patinkin, D.

(1977) Indexation in Israel. Chapter 15 in Erik Lundberg, ed, Inflation Theory and Anti-Inflation Policy, Macrillan, London.

Bruno, M.

(1983) External Shocks and Domestic Response: Israel's Macroeconomic Performance 1965-1982, unpublished, Hebrew University of Jerusalem.

Fischer, $\mathrm{S}$.

(1982) Monetary Policy in Israel. Bank of Israel Economic Review, No. 53 (May), pp.5-30.

and Frenkel, J.

(1981) Resee.rch Jssues Arising from the Current Inflation in Israel, unpublished.

Fraenkel, M.

(1979) Inflation, Floating Exchange Pates and Monetary Policy, unpublished.

Halevi, N., and Klinov-Malul, R.

(1968) The Economic Development of Israel, Praeger, New York. Karni, E.

(1979) The Israeli Economy, 1973-1976: A Survey of Recent Developments and a Review of an Old Problem, Economic Development and Cultural Change. 
Kleiman, E.

(1977) Monetary Correction and Indexation: The Brazilian and Israeli Experience, Explorations in Economic Research (NBER), 4, 1, (Winter), pp.141-176.

Kravis, I., Heston, A. and Sumners, R.

(1978) Real GDP Per Capita for Hore than One Hundred Countries, Economic Journal, June, pp.215-242.

Melnick, R., and sokoler, M.

(1983) The Government's Revenue froin Money Creation and the Inflationary Effects of a Decline in the Rate of Growth of GNP, ioxthcoming Journal of Monetary Econcmics.

Michaely, M.

(1975) Foreign Trade Regimes and Economic Development: Israel (NBER), Columbia University Press, New York.

Patkinkin, D.

(1970) The Economic Development of Israel, unpublished manuscript, Falk institute, Jərusalem.

Shiffer, Z.

(1982) Money and Inflation in Israel: the Transition of an Economy to High Inflation, Federal Reserve Bank of St. Louis Review, 64, 7 (Aug/Sept), pp.28-40.

Sussman, Z.

(1979) Floating with a High Rate of Inflation, in Bank of Israel, The Role of Central Banks in Economic Decision Making, Jerusalem. 